\title{
顎関節形態および前歯部被蓋状態が 前方滑走運動に及ぼす影響
}

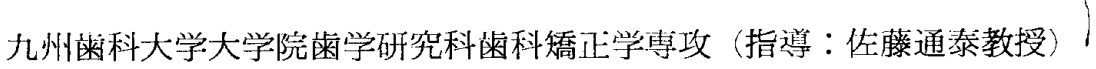

白上清司

昭和56年12月 24 日受付

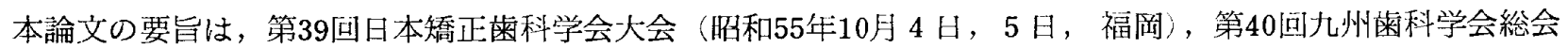

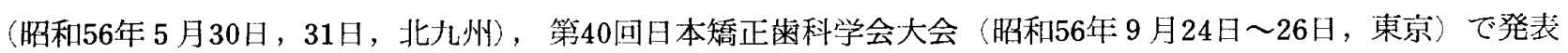
した。

Effects of Temporomandibular Joint Morphology

and Incisal Guidance on Protrusive Excursion

Seiji Shiratsuchi

Department of Orthodontics (Director: Prof. Michiyasu Sato)

Kyushu Dental College, Kitakyushu, Japan.

Maxillary central incisors are important as a dental factor of protrusive excursion. However, most orthodontists decide upon the relationship of maxillary central incisors without considering protrusive excursion in order to improve the function of mandibular movements and esthetics of facial profile.

In the present study, to obtain data on the effects of changed incisal guidance on protrusive excursion, fifteen adult male subjects with normal occlusion and another fifteen adult male subjects with maxillary protrusion were selected, and records of the temporomandibular joint morphology and protrusive excursion were made using cephalometric laminagraph. In addition, data of protrusive excursion were collected when incisal guidance was experimentally changed on subjects with maxillary protrusion. Using this information, the effects of the temporomandibular joint morphology and incisal guidance on protrusive excursion were examined.

The following results were obtained.

1. In cephalometric laminagraph, the depth of cut through the center of the condyle was a very effective method in which to examine the temporomandibular joint morphology and condyle path.

2. There was no significant difference in the temporomandibular joint morphology between the subjects with normal occlusion and those with maxillary protrusion.

3. There were significant differences in the condyle path from the intercuspal occlusal position to the edge-to-edge occlusal position between the subjects with normal occlusion and those with maxillary protrusion, and values of the angle and distance were bigger in the subjects with maxillary protrusion than in those with normal 
occlusion .

4. There was a correlation between the condyle path from the intercuspal occlusal position to the most anterior occlusal position and the inclination of articular eminence in the subjects with normal occlusion or with maxillary protrusion.

5. There were no correlations between the condyle path from the intercuspal occlusal position to the edge-to-edge occlusal position, and the inclinations of the articular eminence and lingual surface of maxillary central incisor, or between the inclination of the lingual surface of maxillary central incisor and the inclination of articular eminence, in the subjects with normal occlusion or with maxillary protrusion.

6. The steeper the incisal guidance was made, the steeper became the condyle path when the incisal guidance was experimentally changed.

The foregoing results suggest that jaw movements alter when the incisal guidance is changed by orthodontic treatment.

Therefore, orthodontists must pay attention to jaw movements and temporomandibular morphology.

緒言

日常の矯正臨床において，矯正家は，機能や審美性の 改善を目的として前歯部被蓋状態の変更を行っている が，前雨のけでもとりわけ上顎中切曾は，顎運動におけ る前方滑走運動の歯牙要素として重要であるといわれて いる”。つまり矯正家は治療術式の中で任意に, 前方滑 走運動の柬牙要素の一つである菌牙路を決定しているこ

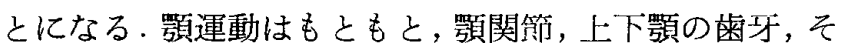
れに顎口腔系の機能を司どる神経筋機棈とによって行わ れているものであるから，治療にさいしては，䫓関節の 形態, 顆頭の動き, それに菌牙路との関連性について知 っておかなければならない、また蕷関節の形態の中でも 特に，前方滑走渾動と関連性のある関節結節の形態は， 混合歯列の前期から中期にかけて結節の高さが增し, 後 壁の傾斜も急になる2'といわれており，小池 $(1970)^{22}$ ， 山内 $\left.(1973)^{3}\right)$ は，関節結節の外形の決定に切歯部が密 接な関係をもつといっている. このように，上顎中切霖 の位置や傾斜は, 前方滑走運動だけでなく, 成長期の関 節形態にも影響を及ぼすものであると考えられている。

顎運動に関する研究は, 古くから行われ, 顎関節の形 態と顆路について見たもの4ー7，顆路と雨牙路とについ て見たもの $8-101 ，$ 䫑関節形態之歯牙路とについて見た もの112などがあるが，澦関節形態と歯牙路と顆路の動 きの三つを同時に見たものはほとんどない，そこで著者 は，䫟関節形態および前歯部被蓋状態が前方滑走運動に 及ぼす影響を知るために，正常咬合者および上額前突者
の, 前方滑走運動時の特定の下顎位をX 線像としてとら えることにより，顎関節形態と顆頭の動きについて検討 を行った．さらに上蕷前突者については，実験的に上顎 前歯の舌面形態を変更し，そのさいの前方滑走運動時の 下顎位をX線像としてとらえ，前歯部被蓋状態と顆頭の 動きについて検討を行い，額関節形態，霜牙路，および 顆頭の動きの関連性について新たな知見を得たので報告 する。

\section{研 究 方 法}

\section{A. 被験者}

九州歯科大学成人男子学生の中から正常咬合者 15 名之 上顎前突者15名の計30名選出した，正常咬合者は， Angle class I で, かつ overjet 2.0〜4.0mm の者, 上顎前突者は，Angle class II で，かつ overjet 5.0 $\mathrm{mm}$ 以上の者とし，両者とも第三大四㐘以外に尔損が なく，矯正治療の既往ならびに顎関節に疼痛および異和 感を挀えたことのない者とした。

正常咬合者, 上顎前突者のセファ口分析の平均值は表 1 に示すとおりである. 成人正常咬合者の平均值に比 較して, 本研究の正常咬合者は skeletal pattern でも denture patternでもほぼ正常值に近い値を示し，上顎 前突者は各項目で上顎前突の特徵を示している。

B . 撮影装置および撮影条件

$\mathrm{X}$ 線撮影には, 九州㐘科大学付属病院放射線科で使用 の以下の装置と方法を用いた。

\section{1. 断層 X線写真撮影}


表1 セファロ分析値

\begin{tabular}{|c|c|c|c|c|}
\hline \multirow[b]{2}{*}{ 計 測 項 目 } & \multicolumn{2}{|c|}{ 正常咬合者 } & \multicolumn{2}{|c|}{ 上蕷前突者 } \\
\hline & $\bar{X}$ & S.D. & $\bar{X}$ & S.D. \\
\hline 1. $\angle \mathrm{SNA}$ & 82.5 & 2.9 & 81.1 & 3.0 \\
\hline 2. $\angle \mathrm{SNB}$ & 80.1 & 3.5 & 76.5 & 3.5 \\
\hline 3. $\angle \mathrm{ANB}$ & 2.4 & 1.8 & 4.5 & 1.6 \\
\hline 4. $\angle \mathrm{SN}-\mathrm{FH}$ & 6.8 & 1.6 & 7.2 & 4.0 \\
\hline 5. $\angle \mathrm{Go}$ & 119.8 & 4.6 & 119.5 & 5.5 \\
\hline 6. $\angle \mathrm{NP}-\mathrm{FH}$ & 86.9 & 3.5 & 84.2 & 2.9 \\
\hline 7. $\angle \mathrm{NAP}$ & 4.5 & 5.8 & 10.0 & $7 \cdot 1$ \\
\hline 8. $\angle \mathrm{AB}-\mathrm{NP}$ & -4.3 & 3.8 & -7.8 & 2.9 \\
\hline 9. $\angle \mathrm{MP}-\mathrm{FH}$ & 24.7 & 6.2 & 25.6 & 4.5 \\
\hline 10. $\angle \mathrm{Y}$-axis & 63.3 & 4.1 & 65.0 & 3.3 \\
\hline 11. $\angle \mathrm{Occ}-\mathrm{FH}$ & $9 \cdot 3$ & 4.8 & 9.5 & 3.8 \\
\hline 12. $\angle \overline{1}-\mathrm{Occ}$ & 23.5 & 5.9 & 27.3 & 5.0 \\
\hline 13. $\angle \overline{1}-\mathrm{MP}$ & 97.4 & 6.8 & 102.6 & 6.2 \\
\hline 14. $\quad 1-\mathrm{NP}$ & 8.9 & 3.0 & 14.3 & 3.3 \\
\hline 15. $1-\mathrm{AP}$ & 8.0 & 2.0 & 11.7 & 2.6 \\
\hline 16. $\angle 1-\overline{1}$ & 122.6 & 9.2 & 113.0 & 9.2 \\
\hline 17. $\angle \mathrm{FH}-1$ & $116 \cdot 3$ & 6.6 & 118.6 & 8.7 \\
\hline 18. overjet & 2.9 & 0.9 & 6.4 & 1.8 \\
\hline 19. overbite & 2.8 & 1.3 & 5.1 & 1.3 \\
\hline
\end{tabular}

単位：度 ただし $14 ， 15 ， 18 ， 19 ： \mathrm{~mm}$

島津製作所製横形断面撮影台 $\mathrm{HL}-5$ 型

管電圧： $\quad 73 \sim 75 \mathrm{Kvp}$

管電流： $70 \mathrm{~mA}$

時間： speed 2

断層角度: $35^{\circ}$

断層深度：36〜 $43 \mathrm{~mm}$

フィルム：フシ RX

2. 後前宣真撮影

ELEMA-SCHÖNANDER 社製頭部精密撮影装置

焦点フィルム䦭距離： $84 \mathrm{~cm}$

管電圧： $77 \mathrm{Kvp}$

管電流： $100 \mathrm{~mA}$

露汒： $0.4 \mathrm{sec}$

リスホルムブレンデ：グリッド比 $6 ： 1$

增感紙：フジハイスクリーン

フィルム：サクラ $\mathrm{QL}$

3. 側貌頭部 X 線規格写真（以下セファロ之略す）撮影

焦点フィルム閻距離： $240 \mathrm{~cm}$

フィルム顔面正中間距離： $12 \mathrm{~cm}$

管電压： $80 \mathrm{Kvp}$

管電流： $200 \mathrm{~mA}$
露出： $\quad 0.25 \mathrm{sec}$

リスホルムブレンデ：グリッド比 $6: 1$

增感紙：フジ八イスクリーン

フィルム：サクラ $\mathrm{QL}$

C . 断層樑度決定法

被験者の皮膚上に平均的顆頭点を求为，そ乙に直径 $5 \mathrm{~mm}$ のスチールボールを貼付し，逆タウン法により $30^{\circ}$ の角度で艾頭嵌命位の後前撮影 ${ }^{2}$ '在行った。各被 験者について，実澌值とフィルム上の距離から抾大率を 求め，年側の顆頭中心点一专虞間距離を計算により求め た。この計算値に頭部規格固定台の厚み $16.0 \mathrm{~mm}$ を加 えたものを断㬝深度とし，次の顎関節規格断層撮影を行 った。

\section{D．提影方法}

1. 顎関節規格断層撮影方法

被験者を断曆撮影台上に腹位に核かせ，頭部だけを真 横にして，頭部規格固定台上に F H 平面が基準線に合う ように頭部を固定し，撮影台上から左側顆頭吣点まで の距離を断層深度として, 咬頭嵌合位, 划端咬合位, 最 前方接触位の 3 種の wax bite 咬ませて，それぞれ

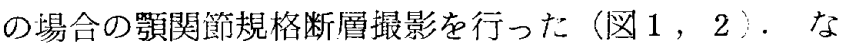

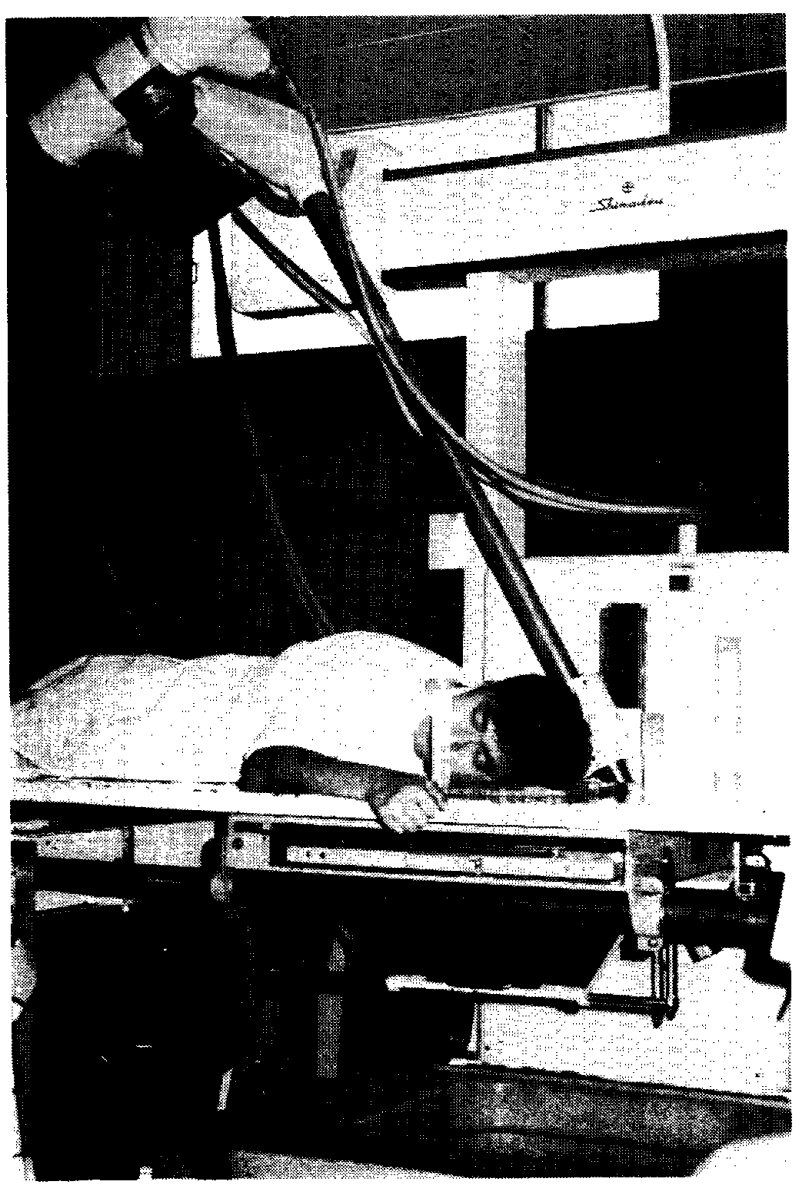

図 1 㖽関節規格断層撮影 


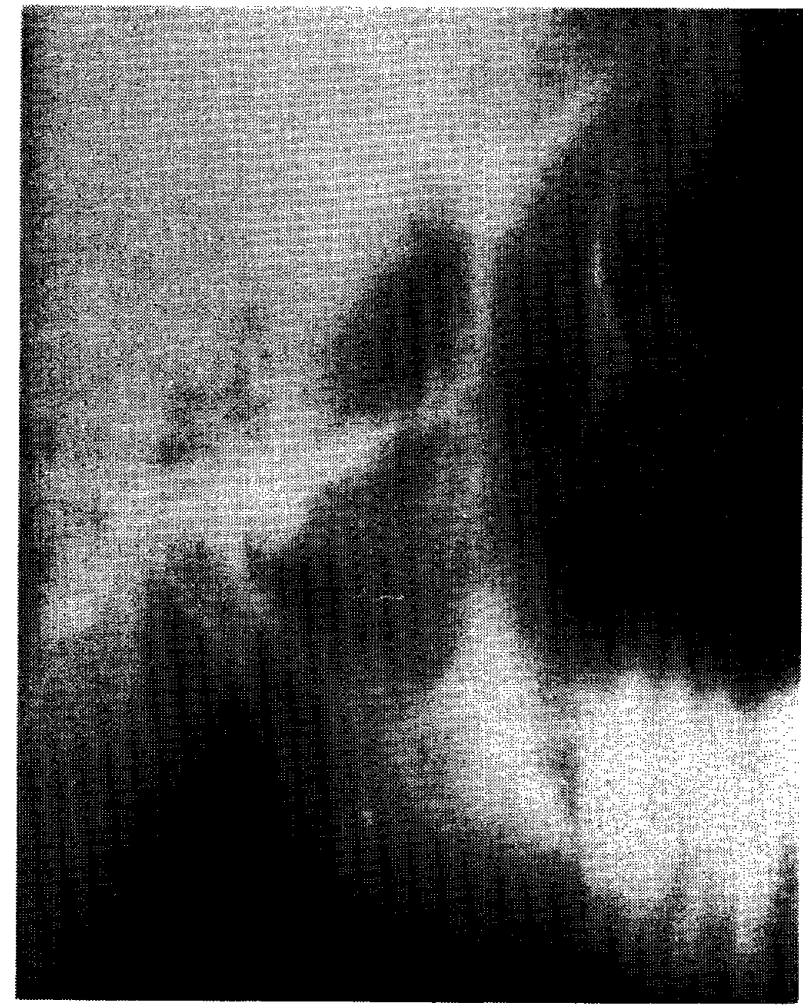

図 2 顎関節規格断層写·真

お，上顎前突者については，上記の撮影の他に，実験的 に被蓋を変更させた場合における切端咬合位。で頢関節 規格断層撮影も行った。

\section{2. 七ファロ撮影方法}

各被験者について咬頭嵌合位でのセファロ撮影を行っ た。なお上顎前突者については, 実験的に被蓋状態を变 更させた場合における切端咬合位でのセファロ撮影も行 った。

E. 前蒾誘㙛板の製作

上顎前突者について夷験的に被瓂状態を変更させるた

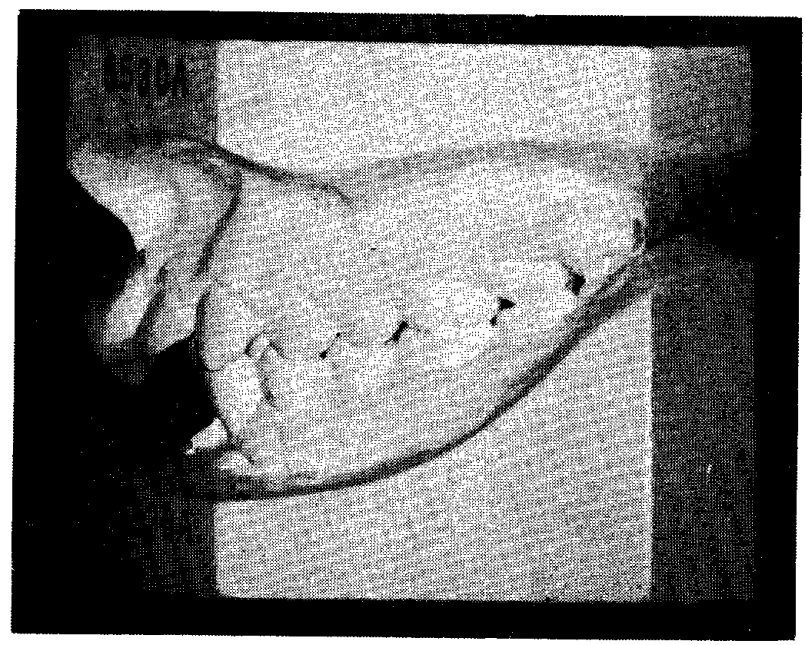

図 3 前 菌 誘 導 板
めに，まず碩態模型を製作し，同模型上で，左側中切畨 舌面傾斜が急になるように，即時重合レジンで前蒾誘導 板を製作した（阀 3 ）。なお前歯誘導板は，咬頭炭合位 では接触がないように，被験者の口腔内で調節を行っ た、前雨誘導板は，咬頭嵌合位から切端咬合位までのト 顎中切柬の移動距離を変えずに，舌面傾斜角ざけを約

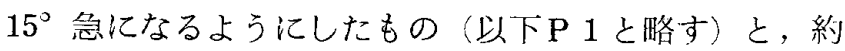
$25^{\circ}$ 急になるようにしたもの（以下 P 2 と略す）， お よび治療後の上顎中切雨舌面の位置をセファ口上で想定 し, overjet が約 $2 \mathrm{~mm}$, overbite が約 $3 \mathrm{~mm}$ になる ようにしたもの (以下P 3 と略す) の計 3 種類を製作し た。これらの前歯誘導板の舌側には，鉛線を貼付し，明 碓なX線像を得るようにした。

F . 計測点と計測項目

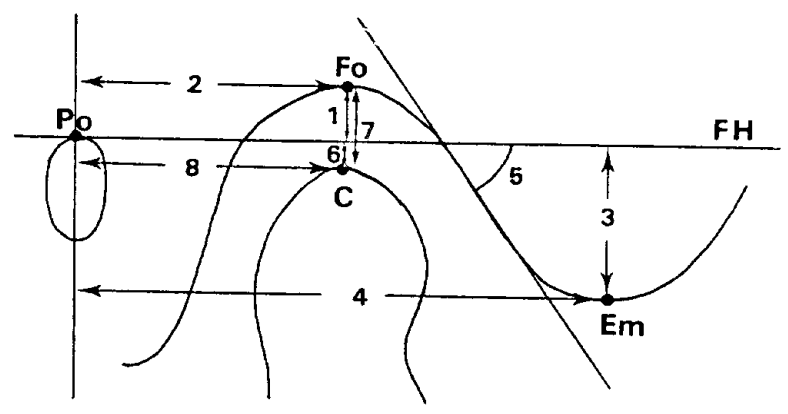

図 4 顎関節形態の計測項目

1. $\mathrm{Fo}_{\mathrm{O}}-\mathrm{FH}$ 2. $\mathrm{Fo}-\mathrm{Po}$ 3. $\mathrm{Em}-\mathrm{FH}$ 4. Em-Po

5. $\angle \mathrm{FH}-\mathrm{Emt}$ 6. $\mathrm{C}-\mathrm{FH}$ 7. $\mathrm{C}-\mathrm{Fo} \quad 8 . \mathrm{C}-\mathrm{Po}$

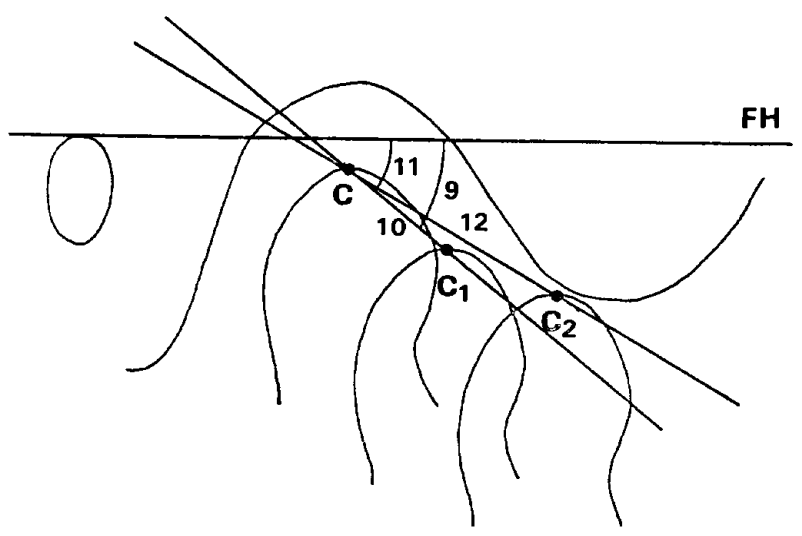

济 5 前方滑走運動時の計測項目
9. $\angle \mathrm{FH}$ to $\mathrm{C}-\mathrm{C}_{1}$
10. $\mathrm{C}-\mathrm{C}_{1}$
11. $\angle \mathrm{FH}$ to $\mathrm{C}-\mathrm{C}_{2}$
12. $\mathrm{C}-\mathrm{C}_{2}$

1. 計測点 (図 4,5 )

Fo：関節窩底

$\mathrm{Em}$ : 関節結節頂 
Po : 耳点

C : 顆頭最高点（咬頭岩合位）

$\mathrm{C}_{1}$ : 顆頭最高点 (切端咬合位)

$\mathrm{C}_{2}$ : 顆頭最高点（最前方接触位）

2. 計测項目

a . 顎関節形態 (図 4)

1) $\mathrm{Fo}-\mathrm{FH}: \mathrm{FH}$ 平面から関節窩底までの㶵直距離.

2) $\mathrm{F}_{0}-\mathrm{Po}: \mathrm{Po}$ から関節窩底までの水平距離.

3) $\mathrm{Em}-\mathrm{FH}: \mathrm{FH}$ 平面から関節結節頂までの垂直距 離.

4) Em-Po:Po から関節結節頂までの水平距離.

5) $\measuredangle \mathrm{FH}-\mathrm{Emt}$ ：関節結節後壁傾斜度. 関節結節後壁 中点における接線 (Emt) と $\mathrm{FH}$ 平面とのなす角度.

6) $\mathrm{C}-\mathrm{FH}: \mathrm{FH}$ 平面から顆頭最高点までの金直距離.

7) $\mathrm{C}-\mathrm{Fo}_{\mathrm{o}}$ : 関節空腺の距離.

8) C-Po：Po から顆頭最高点までの水平距離.

b . 前方滑走運動時の顆頭の動き（図 5 )

9) $\angle \mathrm{FH}$ to $\mathrm{C}-\mathrm{C}_{1}$ ：咬頭嵌合位と切端咬合位の顆頭 最高点を結んだ線と FH 平面 とのなす角度。

10) $\mathrm{C}-\mathrm{C}_{1}$ : 咬頭嵌合位から切端咬合位までの顆頭最高 点の移動距離.

11) $\angle \mathrm{FH}$ to $\mathrm{C}-\mathrm{C}_{2}$ ：咬頭嵌合位と最前方接触位の顆 頭最高点を結んだ線と FH平面 のなす为度。

12) $\mathrm{C}-\mathrm{C}_{2}$ : 咬頭嵌合位から最前方接触位までの顆頭最 高点の移動距離.

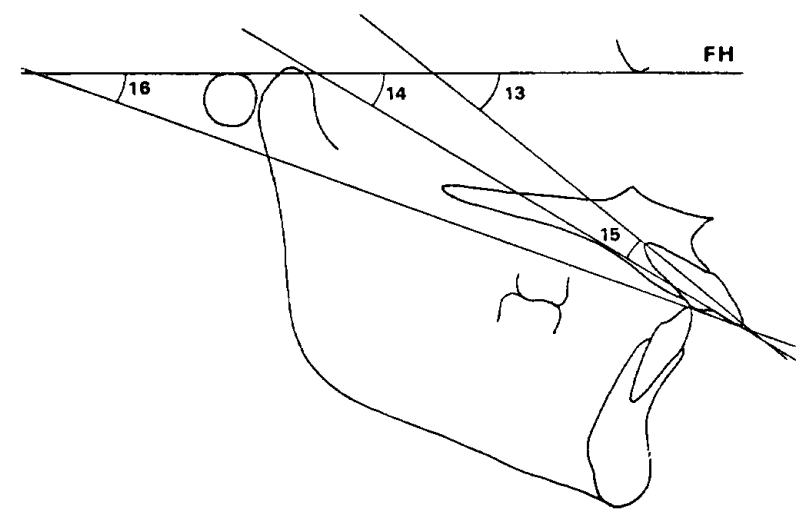

図 6 前雪部被蓋状態の計測項目
13. $\angle \mathrm{FH}-1$
14. $\angle \mathrm{FH}-1 \mathrm{~L}$
15. $\angle 1-1 \mathrm{~L}$
16. $\angle \mathrm{FH}-\underline{1} \overline{1}$

c . 前歯部被蓋状態（図 6 )

13) $\angle \mathrm{FH}-1$ : 歯軸傾斜角. $\mathrm{FH}$ 平面に対する 1 の歯 軸角で, 通常のセファロ分析で計測して いる角の補角.

14) $\angle \mathrm{FH}-1 \mathrm{~L}$ : 舌面傾斜角. 上顎中切歯辺縁隆線と FH 平面のなす角で, 前方滑走運動時 に下䪽前画が滑走していく斜面.

15） $\angle 1-1 \mathrm{~L}$ ：西軸傾斜と舌面傾斜とのなす角度.

16) $\angle \mathrm{FH}-1 \overline{1}$ ：上下顎中切歯の切端を結んだ線と FH 平面とのなす角で, 矢状切菊路 角に相当する.

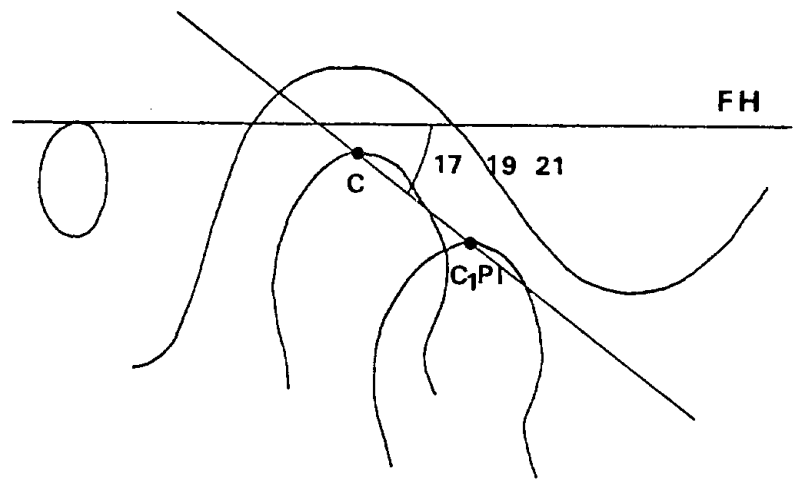

図 7 実験的被蓋変更時の計測項目

17. $\mathrm{P} 1 \angle \mathrm{FH}$ to $\mathrm{C}-\mathrm{C}_{1}$ 19. $\mathrm{P} 2 \angle \mathrm{FH}$ to $\mathrm{C}-\mathrm{C}_{1}$ 21. $\mathrm{P} 3 \angle \mathrm{FH}$ to $\mathrm{C}-\mathrm{C}_{1}$

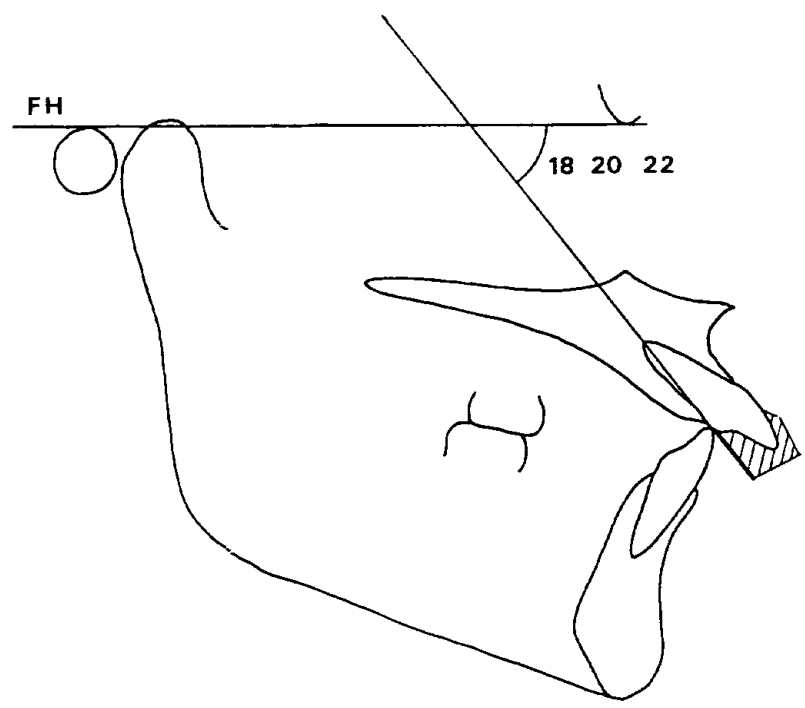

図 8 実験的被蓋変更時のセファロ上での計測項目
18. $\mathrm{P} 1 \angle \mathrm{FH}-1$
20. $\mathrm{P} 2 \angle \mathrm{FH}-\underline{1} \overline{1}$
22. $\mathrm{P} 3 \angle \mathrm{FH}-1 \overline{1}$ 
d. 実験的被蓋変更時（図 7,8 ）

17) $\mathrm{P} 1 \angle \mathrm{FH}$ to $\mathrm{C}-\mathrm{C}_{1}: \mathrm{P}_{1}$ 装着時の咬頭嵌合位と 切端咬合位の顆頭最高点を結 んだ線と FH 平面とのなす 角.

18） $\mathrm{P} 1 \angle \mathrm{FH}-1 \overline{1}: \mathrm{P} 1$ 装着時の矢状切雬路角.

19) $\mathrm{P} 2 \angle \mathrm{FH}$ to $\mathrm{C}-\mathrm{C}_{1}: \mathrm{P} 2$ 装着時の咬頭嵌合位之切 端咬合位の顆頭最高点を結ん だ線と FH 平面とのなす角.

20) $\mathrm{P} 2 \angle \mathrm{FH}-1 \overline{1}: \mathrm{P} 2$ 装着時の矢状切茵路急.

21） P $3 \angle \mathrm{FH}$ to $\mathrm{C}-\mathrm{C}_{1}: \mathrm{P} 3$ 装着時の咬頭嵌合位と切 端咬合位の顆頭最高点を結ん だ線と FH 平面とのなす角.

22) P $3 \angle \mathrm{FH}-1 \overline{1}: \mathrm{P} 3$ 装着時の矢状切歯路角.

な㧍，トレースには，アセテート紙を用い，三豊製 1 級ノギス（1/20 mm 副尺付）抢よび製図用分度器を使 用して計測を行った. 計測は各 5 回行い，その平均值を 計測值とした。

G . 測定精度検定

この方法において生じる测定誤差は，X線撮影装置の 精度と，トレースおよび計測䛊差との二つに大別するこ とができる。

\section{1. $\mathrm{X}$ 線撮影装置の精度}

本研究で使用した水平移動式断層撮影装算 $\mathrm{HL}-5$ 型 の精度に関して, 中尾(1969)13'は次のように報告し ている、すなわち装置の移動に伴うガタや写真のボケは 無く, 拡大率は断層角度変化にあまり左右されずに，断 屬深度の高低によって変化し, 計測值は理論值で処理で きると述べている．このことから，撮影装置の精度はこ の史験に影響を与えることはなく，桩大率を計算により 求めればよいことになる（図 9 ，表 2 ).

すなわち，次式の通りである。

$A+B: A=L^{\prime} M^{\prime}: L M \quad \therefore$ 抾大率 $\frac{L^{\prime} M^{\prime}}{L M}=\frac{A+B}{A}$

ただし $\mathrm{A}$ ：焦点回転中心軸間距離， $\mathrm{B}$ ：回転中心軸 フィルム間距離, $\mathrm{L} \mathrm{M}$ : 被写体, $\mathrm{L}^{\prime} \mathrm{M}^{\prime}$ : 被写体のフィ ルム上の拡大像である。これにより実長二実測值／昖 大率として算出した.

2. トレースおよび計測の誤差

被験者を撮影したX線フィルムを 3 回トレースし，各 計測点を 5 回づつ測定し, 各トレース間に生ずるばらつ きを求めた。この結果, 計測值の誤差は, 距離計測で士 $0.25 \mathrm{~mm}$ 以内, 角度計測で $\pm 1.0^{\circ}$ 以内であることが 分った.

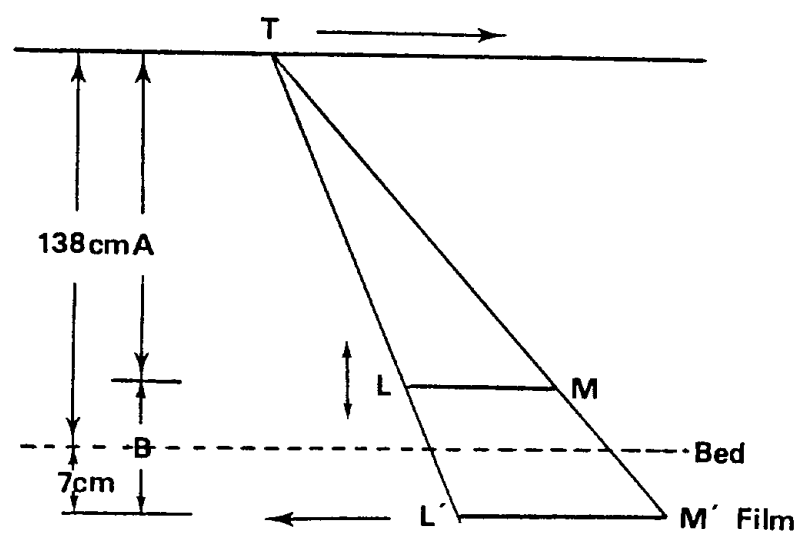

図 9 断層撮影の㹡大率

$\mathrm{T}$ ：焦点 $\mathrm{L}$ ：回転中心軸

$\mathrm{A}$ : 焦点 - 回転中心軸間距離

$\mathrm{B}$ ：回転中心軸・フィルム間距離

$\mathrm{L} \mathrm{M}$ : 被写体 $\mathrm{L}^{\prime} \mathrm{M}^{\prime}$ ：フィルム上の拡大像

表 2 断層撮影の扰大率

\begin{tabular}{c|c}
\hline 断凮深度 & 拡 大 率 \\
\hline $36 \mathrm{~mm}$ & 1.078 \\
37 & 1.079 \\
38 & 1.080 \\
39 & 1.081 \\
40 & 1.082 \\
41 & 1.082 \\
42 & 1.083 \\
43 & 1.084 \\
\hline
\end{tabular}

研 究 結 果

前章で述べた研究方法により計測を行った結果，以下 のような測定結果を得た.

A . 顆頭中心点一皮䖉間距離および断首深度

表 3 に示すように, 顆頭中心点一皮膚間距離は，正常 咬合者で最小 $19.9 \mathrm{~mm}$, 最大 $26.8 \mathrm{~mm}$, 平均 $23.1 \pm$ $1.6 \mathrm{~mm}$ であり，上䝷前突者で最小 $20.7 \mathrm{~mm}$ ，最大 $26.5 \mathrm{~mm}$, 平均 $23.4 \pm 1.6 \mathrm{~mm}$ であった。

断層深度は，顆頭中心点一皮虐間距離に頭部規格固 定台の厚み $16.0 \mathrm{~mm}$ を加えたものであるので，36〜43 $\mathrm{mm}$ の間であった。

B . 顎関節形態

計測にあたり，計測点が $\mathrm{FH}$ 平面よりも上方にある 場合を（一)，下方にある場合を（十）とした。

1. 正常咬合者（表 4 ） 
表 3 顆頭中心点一皮膚間距離および断層深度

\begin{tabular}{|c|c|c|c|c|}
\hline \multirow[b]{2}{*}{ 被験者 } & \multicolumn{2}{|c|}{ 正常咬合者 } & \multicolumn{2}{|c|}{ 上 顎 前㔖者 } \\
\hline & $\begin{array}{l}\text { 顆頭中心点閵 } \\
\text { 路敨成 }\end{array}$ & 断居深度 & $\begin{array}{l}\text { 顆頭中心点 } \\
\text { 鬲間距離 }\end{array}$ & 断凰深度 \\
\hline 1. & 24.0 & 40 & 26.5 & 43 \\
\hline 2 . & 21.7 & 38 & 21.7 & 38 \\
\hline 3. & 23.0 & 39 & 20.7 & 37 \\
\hline 4. & 22.2 & 38 & 24.2 & 40 \\
\hline 5. & 24.2 & 40 & 24.8 & 41 \\
\hline 6. & 23.5 & 40 & 22.5 & 39 \\
\hline 7 & 24.2 & 40 & 23.4 & 39 \\
\hline 8. & 19.9 & 36 & 24.2 & 40 \\
\hline 9. & 22.0 & 38 & 23.4 & 39 \\
\hline 10 & 22.4 & 38 & 22.5 & 39 \\
\hline 11 . & 22.9 & 39 & 24.2 & 40 \\
\hline 12 & 26.8 & 43 & 23.1 & 39 \\
\hline 13. & 22.1 & 38 & 25.3 & 41 \\
\hline 14 & 24.2 & 40 & 23.6 & 39 \\
\hline 15. & 23.3 & 39 & 21.1 & 37 \\
\hline$\overline{\mathrm{X}}$ & 23.1 & & 23.4 & \\
\hline S.D. & 1.6 & & 1.6 & \\
\hline
\end{tabular}

単位: $\mathrm{mm}$

表 4 顎関節形態の計測値（正常咬合者）

\begin{tabular}{c|r|r|r|r|r|r|r|r}
\hline 被験者 & $\mathrm{Fo}-\mathrm{FH}$ & $\mathrm{Fo}-\mathrm{Po}$ & $\mathrm{Em}-\mathrm{FH}$ & $\mathrm{Em}-\mathrm{Po}$ & $\angle \mathrm{FH}-\mathrm{Emt}$ & $\mathrm{C}-\mathrm{FH}$ & $\mathrm{C}-\mathrm{Fo}$ & $\mathrm{C}-\mathrm{Po}$ \\
\hline 1. & -1.3 & 11.0 & 3.7 & 20.9 & 33.0 & 1.3 & 2.6 & 10.6 \\
2. & -1.2 & 12.2 & 6.3 & 22.9 & 45.5 & -0.3 & 0.9 & 12.0 \\
3. & -1.2 & 14.9 & 8.6 & 23.5 & 48.0 & 3.1 & 4.3 & 13.2 \\
4. & -2.1 & 11.2 & 6.0 & 22.1 & 51.0 & 1.0 & 3.1 & 11.2 \\
5. & -0.7 & 12.1 & 8.2 & 22.6 & 52.5 & 1.6 & 2.3 & 12.6 \\
6. & -2.3 & 13.7 & 7.0 & 25.3 & 55.0 & 0.3 & 2.6 & 12.1 \\
7. & -0.6 & 10.7 & 7.4 & 20.5 & 56.0 & 3.5 & 4.1 & 10.0 \\
8. & 2.2 & 11.2 & 8.2 & 19.9 & 56.5 & 2.8 & 0.6 & 12.1 \\
9. & 0 & 13.7 & 7.9 & 24.3 & 56.5 & 2.5 & 2.5 & 12.8 \\
10. & 1.8 & 12.3 & 8.1 & 20.5 & 57.0 & 2.9 & 1.1 & 12.5 \\
11. & -2.5 & 12.5 & 5.9 & 22.8 & 57.5 & 0.7 & 3.2 & 12.4 \\
12. & -0.8 & 13.6 & 9.2 & 24.1 & 57.5 & 1.9 & 2.7 & 13.8 \\
13. & 2.7 & 13.6 & 10.0 & 22.3 & 59.0 & 4.8 & 2.1 & 12.6 \\
14. & -3.6 & 10.8 & 5.3 & 19.4 & 67.0 & -1.0 & 2.6 & 10.5 \\
15. & -1.7 & 14.8 & 8.2 & 25.1 & 69.0 & 0.8 & 2.5 & 13.4 \\
\hline$\overline{\mathrm{X}}$ & -0.8 & 12.6 & 7.3 & 22.4 & 54.7 & 1.7 & 2.5 & 12.1 \\
\hline S.D. & 1.8 & 1.4 & 1.6 & 1.9 & 8.5 & 1.4 & 1.0 & 1.1 \\
\hline
\end{tabular}

単位: $\mathrm{mm}$ ただし $\angle \mathrm{FH}-\mathrm{Emt}$ : 度 


\section{a . 関節窩底の位管}

Fo-FH は最小 $-3.6 \mathrm{~mm}$, 最大 $2.7 \mathrm{~mm}$, 平均 $0.8 \pm 1.8 \mathrm{~mm}$ で, Fo-Po は最小 $10.7 \mathrm{~mm}$, 最大 $14.9 \mathrm{~mm}$, 平均 $12.6 \pm 1.4 \mathrm{~mm}$ であった。

b. 関節結節頂の位置

$\mathrm{Em}-\mathrm{FH}$ は最小 $3.7 \mathrm{~mm}$, 最大 $10.0 \mathrm{~mm}$, 平均 7.3 $\pm 1.6 \mathrm{~mm}$ で, Em-Po は最小 $19.4 \mathrm{~mm}$, 最大 25.3 $\mathrm{mm}$, 平均 $22.4 \pm 1.9 \mathrm{~mm}$ であった。

\section{c . 関節結節後壁傾斜度}

$\angle \mathrm{FH}-\mathrm{Emt}$ は最小 $33.0^{\circ}$, 最大 $69.0^{\circ}$, 平均 54.7 $\pm 8.5^{\circ}$ であった.

d. 咬頭嵌合位時の顆頭位

C一FH は最小 $-1.0 \mathrm{~mm}$, 最大 $4.8 \mathrm{~mm}$, 平均 1.7 $\pm 1.4 \mathrm{~mm}$ で, C-Fo は最小 $0.6 \mathrm{~mm}$, 最大 $4.3 \mathrm{~mm}$, 平均 $2.5 \pm 1.0 \mathrm{~mm}$ であり，C-Po は最小 $10.0 \mathrm{~mm}$, 最大 $13.8 \mathrm{~mm}$, 平均 $12.1 \pm 1.1 \mathrm{~mm}$ であった。

表 5 顎 関 節 形態 の計测 值 (上顎 前突 者)

\begin{tabular}{|c|c|c|c|c|c|c|c|c|}
\hline 被験者 & $\mathrm{Fo}_{0}-\mathrm{FH}$ & $\mathrm{Fo}_{0}-\mathrm{Po}_{0}$ & $\mathrm{Em}-\mathrm{FH}$ & $\mathrm{Em}-\mathrm{Po}$ & $\angle \mathrm{FH}-\mathrm{Emt}$ & $\mathrm{C}-\mathrm{FH}$ & $\mathrm{C}-\mathrm{Fo}_{\mathrm{o}}$ & $\mathrm{C}-\mathrm{Po}$ \\
\hline 1. & -1.2 & 11.8 & 5.8 & 21.5 & 50.0 & 1.7 & 2.8 & 10.7 \\
\hline 2 . & 2.2 & 13.3 & 8.5 & 22.5 & 51.0 & 4.2 & 2.0 & 12.8 \\
\hline 3. & 0.8 & 10.5 & 8.5 & 23.0 & 53.5 & 2.4 & 1.6 & 10.5 \\
\hline 4 & -0.9 & 11.3 & 6.9 & 20.7 & 54.0 & 0 & 0.9 & 10.7 \\
\hline 5 . & -0.5 & 14.2 & 7.7 & 24.6 & 55.0 & 0.4 & 0.8 & 15.0 \\
\hline 6. & -1.1 & 13.2 & 7.8 & 22.9 & 58.0 & 0 & $1 \cdot 1$ & 12.8 \\
\hline 7 . & -1.1 & 12.9 & 7.6 & 23.2 & 58.0 & 2.3 & 3.4 & 13.6 \\
\hline 8. & -1.2 & 13.4 & 5.6 & 25.2 & 58.5 & 1.4 & 2.6 & $16 \cdot 3$ \\
\hline 9 . & 1.1 & 9.6 & 9.9 & 23.3 & 59.0 & 2.6 & 1.5 & 12.0 \\
\hline 10 & 0 & 13.8 & 9.3 & $24 \cdot 3$ & 60.0 & 3.1 & 3.1 & 11.9 \\
\hline 11 . & -1.8 & 12.2 & 5.2 & 20.7 & 60.0 & 1.0 & 2.8 & 11.5 \\
\hline 12 . & 1.8 & 12.9 & 9.9 & 23.3 & 61.5 & 3.2 & 1.5 & 13.9 \\
\hline 13. & -1.6 & 13.5 & 7.5 & 23.8 & 63.0 & 1.0 & 2.6 & 11.2 \\
\hline 14. & 0.5 & 14.2 & 7.8 & 23.2 & 65.5 & 3.0 & 2.5 & 14.3 \\
\hline 15 & 3.4 & 13.3 & 11.5 & 24.8 & 68.0 & $4 \cdot 2$ & 0.8 & 13.7 \\
\hline$\overline{\mathrm{X}}$ & 0 & 12.7 & 8.0 & 23.1 & 58.3 & 2.0 & 2.0 & 12.7 \\
\hline S.D. & 1.6 & 1.3 & 1.7 & 1.4 & 5.1 & 1.4 & 0.9 & 1.7 \\
\hline
\end{tabular}

単位：mm ただし $\angle \mathrm{FH}-\mathrm{Emt}$ : 度

\section{2. 上顎前突者（表 5 ）}

\section{a . 関節窩底の位置}

Fo-FH は最小 $-1.8 \mathrm{~mm}$, 最大 $3.4 \mathrm{~mm}$, 平均 0 $\pm 1.6 \mathrm{~mm}$ で, Fo-Po は最小 $9.6 \mathrm{~mm}$, 最大 $14.2 \mathrm{~mm}$, 平均 $12.7 \pm 1.3 \mathrm{~mm}$ であった.

b. 関節結節頂の位置

$\mathrm{Em}-\mathrm{FH}$ は最小 $5.2 \mathrm{~mm}$, 最大 $11.5 \mathrm{~mm}$, 平均 8.0 $\pm 1.7 \mathrm{~mm}$ で， $\mathrm{Em}-\mathrm{Po}$ は最小 $20.7 \mathrm{~mm}$ ，最大 25.2 $\mathrm{mm}$, 平均 $23.1 \pm 1.4 \mathrm{~mm}$ であった。

c. 関節結節後壁傾斜度

$\angle \mathrm{FH}-\mathrm{Emt}$ は最小 $50.0^{\circ}$, 最大 $68.0^{\circ}$, 平均 58.3 土5.1 $1^{\circ}$ であった。

d. 咬頭嵌合位時の顆頭位

$\mathrm{C}-\mathrm{FH}$ は最小 $0 \mathrm{~mm}$, 最大 $4.2 \mathrm{~mm}$, 平均 $2.0 \pm$
$1.4 \mathrm{~mm}$ で， C-Fo は最小 $0.8 \mathrm{~mm}$ ，最大 $3.4 \mathrm{~mm}$, 平均 $2.0 \pm 0.9 \mathrm{~mm}$ であり, C-Poは最小 $10.5 \mathrm{~mm}$, 最大 $16.3 \mathrm{~mm}$, 平均 $12.7 \pm 1.7 \mathrm{~mm}$ であった。

C . 前方滑走運動時の顆頭最高点の動き

1. 正常咬合者（表 6 )

a 、咬頭岸合位汃ら切端咬合位に至る顆頭最高点の動 き

咬頭嵌合位と切端咬合位の顆頭最高点を結んだ線が $\mathrm{FH}$ 平面となす角度 $\angle \mathrm{FH}$ to $\mathrm{C}-\mathrm{C}_{1}$ は最小 $23.5^{\circ}$ ，最 大 $45.0^{\circ}$, 平均 $35.6 \pm 7.2^{\circ}$ であった。 その時の顆頭 最高点の移動距離 $\mathrm{C}-\mathrm{C}_{1}$ は, 最小 $1.2 \mathrm{~mm}$, 最大 6.0 $\mathrm{mm}$, 平均 $3.1 \pm 1.3 \mathrm{~mm}$ であった。

b . 咬頭嵌合位から最前方接触位にに至る顆頭最高点の 動き 
表 6 前方滑走運動時の計測值（正常咬合者）

\begin{tabular}{|c|c|c|c|c|}
\hline 被験者| & $\angle \underset{\mathrm{CH}}{\mathrm{F}}-\mathrm{C}_{1}$ & $\mathrm{C}-\mathrm{C}_{1}$ & $\begin{array}{r}\angle \mathrm{FH} \text { to } \\
\mathrm{C}-\mathrm{C}_{2}\end{array}$ & $\mathrm{C}-\mathrm{C}_{2}$ \\
\hline 1. & $24.5^{\circ}$ & $1.5 \mathrm{~mm}$ & $21.0^{\circ}$ & $4.9 \mathrm{~mm}$ \\
\hline 2. & 33.0 & 5.1 & 36.5 & 9.9 \\
\hline 3. & 43.5 & 3.1 & 24.0 & 12.5 \\
\hline 4. & 23.5 & 2.7 & 29.0 & 5.2 \\
\hline 5. & 45.0 & 6.0 & 40.5 & 11.1 \\
\hline 6. & 31.0 & 2.8 & 39.0 & 7.8 \\
\hline 7. & 29.5 & 3.6 & 23.0 & 10.2 \\
\hline 8. & 38.5 & 3.9 & 27.5 & 10.9 \\
\hline 9. & 30.5 & 1.2 & 38.0 & 4.9 \\
\hline 10 & 31.0 & 1.7 & 35.5 & 7.3 \\
\hline 11. & 37.0 & 2.7 & 32.5 & 9.9 \\
\hline 12 . & 44.5 & 3.6 & 44.5 & 8.0 \\
\hline 13. & 44.0 & 2.8 & 40.0 & 7.1 \\
\hline 14 . & 42.0 & 3.3 & 50.0 & 6.6 \\
\hline 15 & 36.5 & 2.9 & 42.0 & 6.8 \\
\hline $\bar{X}$ & 35.6 & 3.1 & 34.9 & 8.2 \\
\hline S.D. & 7.2 & 1.3 & 8.5 & 2.4 \\
\hline
\end{tabular}

咬頭嵌合位と最前方接触位の顆頭最高点を結んだ線と $\mathrm{FH}$ 平面とのなす角度 $\angle \mathrm{FH}$ to $\mathrm{C}-\mathrm{C}_{2}$ は, 最小 $21.0^{\circ}$, 最大 $50.0^{\circ}$, 平均 $34.9 \pm 8.5^{\circ}$ であった。 その時の顆

表 7 前方滑走運動時の計測值（上嘖前突者）

\begin{tabular}{|c|c|c|c|c|}
\hline 被験者 & $\begin{array}{r}\angle \mathrm{FH} \text { to } \\
\mathrm{C}-\mathrm{C}_{1}\end{array}$ & $\mathrm{C}-\mathrm{C}_{1}$ & $\begin{array}{c}\angle \mathrm{FH} \text { to } \\
\mathrm{C}-\mathrm{C}_{2}\end{array}$ & $\mathrm{C}-\mathrm{C}_{2}$ \\
\hline 1. & $38.0^{\circ}$ & $6.5 \mathrm{~mm}$ & $34.0^{\circ}$ & $8.2 \mathrm{~mm}$ \\
\hline 2. & 45.5 & 7.3 & 41.5 & 10.4 \\
\hline 3. & 34.0 & 5.8 & 26.5 & 11.5 \\
\hline 4. & 49.0 & 7.6 & 39.0 & 11.9 \\
\hline 5. & 51.5 & 7.5 & 51.5 & 9.5 \\
\hline 6. & 48.0 & 3.7 & 36.5 & 9.3 \\
\hline 7. & 48.5 & 4.6 & 47.0 & 6.7 \\
\hline 8. & 30.5 & 5.8 & 27.0 & 10.6 \\
\hline 9. & 39.0 & 11.6 & 35.0 & 13.1 \\
\hline 10. & 44.5 & 6.6 & 38.5 & 7.8 \\
\hline 11. & 45.5 & 5.2 & 47.0 & 8.2 \\
\hline 12 . & 35.0 & 10.6 & 30.0 & 14.2 \\
\hline 13. & 41.5 & 9.3 & 36.0 & 12.0 \\
\hline 14 . & 29.0 & 8.6 & 22.5 & 12.0 \\
\hline 15. & 55.0 & 5.6 & 45.0 & 11.1 \\
\hline $\bar{X}$ & 42.3 & 7.1 & 37.1 & 10.4 \\
\hline S.D. & 7.8 & 2.2 & 8.4 & 2.1 \\
\hline
\end{tabular}

頭最高点の移動距離 $\mathrm{C}-\mathrm{C}_{2}$ は. 最小 $4.9 \mathrm{~mm}$, 最大 $12.5 \mathrm{~mm}$, 平均 $8.2 \pm 2.4 \mathrm{~mm}$ であった。

2. 上顎前突者 (表 7 )

a . 咬頭嵌合位汃引切端咬合位に至る顆頭最高点の動 き

両位置におうるる顆頭最高点を結んだ線が $\mathrm{FH}$ 平面とな す角度 $\angle \mathrm{FH}$ to $\mathrm{C}-\mathrm{C}_{1}$ は, 最小 $29.0^{\circ}$, 最大 $55.0^{\circ}$, 平均 $42.3 \pm 7.8^{\circ}$ であった。（その時の顆頭最高点の移 動距離 $\mathrm{C}-\mathrm{C}_{1}$ は最小 $3.7 \mathrm{~mm}$, 最大 $11.6 \mathrm{~mm}$, 平均 $7.1 \pm 2.2 \mathrm{~mm}$ であった。

b . 咬頭嵌合位汃ら最前方接触位に至る顆頭最高点の 動き

両位置における顆頭最高点を結んだ線が $\mathrm{FH}$ 平面とな す角度 $\angle \mathrm{FH}$ to $\mathrm{C}-\mathrm{C}_{2}$ は, 最小 $22.5^{\circ}$, 最大 $51.5^{\circ}$, 平均 $37.1 \pm 8.4^{\circ}$ であった. その時の顆頭最高点の移 動距離 $\mathrm{C}-\mathrm{C}_{2}$ は, 最小 $6.7 \mathrm{~mm}$, 最大 $14.2 \mathrm{~mm}$, 平均 $10.4 \pm 2.1 \mathrm{~mm}$ であった。

D . 前䨑部被蓋状態

表 8 前歯部被蓋状態の計測值（正常咬合者）

\begin{tabular}{c|c|c|r|r}
\hline \hline 被験者 & $\angle \mathrm{FH}-1$ & \multicolumn{1}{|c|}{$\mathrm{FH}-1 \mathrm{~L}$} & $\angle 1-1 \mathrm{~L}$ & $\angle \mathrm{FH}-1 \overline{1}$ \\
\hline 1. & 65.5 & 61.0 & 4.5 & 37.5 \\
2. & 73.5 & 68.5 & 5.0 & 60.0 \\
3. & 63.5 & 64.0 & -0.5 & 28.0 \\
4. & 49.5 & 43.5 & 6.0 & 37.0 \\
5. & 68.0 & 58.0 & 10.0 & 54.5 \\
6. & 66.0 & 69.5 & -3.5 & 32.5 \\
7. & 64.0 & 52.0 & 12.0 & 52.0 \\
8. & 58.5 & 52.0 & 6.5 & 46.5 \\
9. & 55.5 & 49.5 & 6.0 & 33.0 \\
10. & 72.5 & 70.0 & 2.5 & 56.5 \\
11. & 63.0 & 53.0 & 10.0 & 31.0 \\
12. & 55.0 & 49.5 & 5.5 & 24.0 \\
13. & 64.0 & 57.0 & 7.0 & 42.5 \\
14. & 69.0 & 67.0 & 2.0 & 61.5 \\
15. & 76.5 & 75.0 & 1.5 & 62.0 \\
\hline $\mathrm{X}$ & 64.3 & 59.3 & 5.0 & 43.9 \\
\hline S.D. & 8.0 & 9.3 & 4.1 & 13.1 \\
\hline & & & & 単位 : 度 \\
\hline & & & &
\end{tabular}

1. 正常咬合者（表 8 )

a . 上顎中切粜幽軸が $\mathrm{FH}$ 平面となす角度 $\angle \mathrm{FH}-$ 1 は, 最小 $49.5^{\circ}$, 最大 $76.5^{\circ}$, 平均 $64.3 \pm 8.0^{\circ}$ で あった・ 
b . 上頢中切幽舌面傾斜が $\mathrm{FH}$ 平面となす角度 $\angle \mathrm{FH}$ $-1 \mathrm{~L}$ は, 最小 $43.5^{\circ}$, 最大 $75.0^{\circ}$, 平均 $59.3 \pm 9.3^{\circ}$ であった。

c . 上顎中切歯の雬軸傾斜之舌面傾斜とのなす角度 $\angle \underline{1}-1 \mathrm{~L} は$, 最小 $-3.5^{\circ}$, 最大 $12.0^{\circ}$, 平均 $5.0 \pm$ $4.1^{\circ}$ であった。

d . 上下顎中切菌切端を結んだ線が $\mathrm{FH}$ 平面となす角 度 $\angle \mathrm{FH}-1 \overline{1}$ は, 最小 $24.0^{\circ}$, 最大 $62.0^{\circ}$, 平均 43.9 $\pm 13.1^{\circ}$ であった。

表 9 前歯部被蓋状態の計測值（上顎前突者）

\begin{tabular}{c|c|c|c|c}
\hline 被験者 & $\angle \mathrm{FH}-1$ & $\angle \mathrm{FH}-\underline{1} \mathrm{~L}$ & $\angle \underline{1}-\underline{1} \mathrm{~L}$ & $\angle \mathrm{FH}-\underline{1} \mathbf{1}$ \\
\hline 1. & 62.5 & 55.5 & 7.0 & 37.0 \\
2. & 62.5 & 61.5 & 1.0 & 53.0 \\
3. & 59.0 & 56.0 & 3.0 & 37.0 \\
4. & 67.0 & 79.0 & -12.0 & 53.0 \\
5. & 59.0 & 50.0 & 9.0 & 37.0 \\
6. & 67.5 & 59.5 & 8.0 & 47.0 \\
7. & 60.0 & 66.5 & -6.5 & 46.5 \\
8. & 68.5 & 75.5 & -7.0 & 56.0 \\
9. & 48.5 & 42.5 & 6.0 & 14.5 \\
10. & 62.0 & 60.5 & 1.5 & 38.5 \\
11. & 75.5 & 90.5 & -15.0 & 63.5 \\
12. & 39.0 & 39.5 & -0.5 & 20.0 \\
13. & 61.0 & 45.5 & 15.5 & 35.0 \\
14. & 69.5 & 66.0 & 3.5 & 41.5 \\
15. & 59.0 & 54.0 & 5.0 & 54.0 \\
\hline $\bar{X}$ & 61.4 & 60.1 & 1.2 & 42.2 \\
\hline $\mathrm{S.D.}$ & 8.7 & 13.9 & 8.3 & 13.3 \\
\hline & & & & \\
\hline
\end{tabular}

単位：度

\section{2. 上顎前突者 (表 9)}

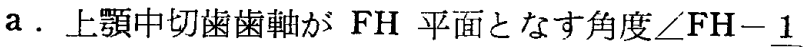
は，最小 $39.0^{\circ}$ ，最大 $75.5^{\circ}$ ，平均 $61.4 \pm 8.7^{\circ}$ であ った。

b . 上顎中切歯舌面傾斜が $\mathrm{FH}$ 平面之なす角度 $\angle \mathrm{FH}$ $-1 \mathrm{~L}$ は, 最小 $39.5^{\circ}$, 最大 $90.5^{\circ}$, 平均 $60.1 \pm 13.9^{\circ}$ であった。

c . 上顎中切歯の蒾軸傾斜と舌面傾斜とのなす角度 $\angle 1-\underline{1} \mathrm{~L}$ は, 最小 $-15.0^{\circ}$, 最大 $15.5^{\circ}$, 平均 $1.2 \pm$ 8.3であった.

d. 上下顎中切雬切端を結んだ線が FH 平面となす 角度 $\angle \mathrm{FH}-1$ 应 は, 最小 $14.5^{\circ}$, 最大 $63.5^{\circ}$, 平均 $42.2 \pm 13.3^{\circ}$ であった。
表10 P 1 装着時の計測值

\begin{tabular}{|c|c|c|c|c|}
\hline 被験者 & $\begin{array}{l}\mathrm{P} 1 \angle \mathrm{FH} \\
\quad-1 \overline{1}\end{array}$ & 変化量 & $\begin{array}{r}\mathrm{P} 1 \angle \mathrm{FH} \text { to } \\
\mathrm{C}-\mathrm{C}_{1}\end{array}$ & 変化量 \\
\hline 1. & 46.0 & 10.0 & 39.0 & 1.0 \\
\hline 2 & 71.0 & 18.0 & 49.5 & 4.0 \\
\hline 3. & 52.0 & 15.0 & 34.5 & 0.5 \\
\hline 4. & 58.0 & 5.0 & 51.0 & 2.0 \\
\hline 5. & 65.0 & 28.0 & 52.5 & 1.0 \\
\hline 6. & 59.0 & 12.0 & 50.5 & 2.5 \\
\hline 7. & 56.0 & 9.5 & 50.5 & 2.0 \\
\hline 8. & 72.0 & 16.0 & 31.0 & 0.5 \\
\hline 9. & 46.0 & 31.5 & 39.5 & 0.5 \\
\hline 10 & 52.0 & 13.5 & 47.5 & 3.0 \\
\hline 11. & 68.0 & 4.5 & 53.0 & 7.5 \\
\hline 12. & 30.0 & 10.0 & 36.0 & 1.0 \\
\hline 13. & 53.0 & 18.0 & 46.5 & 5.0 \\
\hline 14. & 54.0 & 12.5 & 32.0 & 3.0 \\
\hline 15. & 69.0 & 15.0 & 57.5 & 2.5 \\
\hline$\overline{\mathrm{X}}$ & 56.7 & 14.6 & 44.7 & 2.4 \\
\hline S.D. & 11.3 & 7.4 & 8.5 & 1.9 \\
\hline
\end{tabular}

E. 実験的被蓋変更時

1. 前歯誘導板 P 1 装着時（表10）

前雨誘導板 $\mathrm{P} 1$ の実験的雬牙誘導は, $\mathrm{P} 1 \angle \mathrm{FH}-$ $1 \overline{1}$ が $\angle \mathrm{FH}-\underline{1} \overline{1}$ よりも $15^{\circ}$ 急になるように製作 したが，七ファロによる実測では $4.5 \sim 31.5^{\circ}$ ，平均 $14.6^{\circ}$ 急であった。

この時の顆頭最高点の動きが $\mathbf{F H}$ 平面となす角度 $\mathrm{P} 1$ $\angle \mathrm{FH}$ to $\mathrm{C}-\mathrm{C}_{1}$ は, 最小 $31.0^{\circ}$ 最大 $57.5^{\circ}$, 平均 $44.7 \pm 8.5^{\circ}$ であった. てれは $\angle \mathrm{FH}$ to $\mathrm{C}-\mathrm{C}_{1}$ より も $0.5 \sim 7.5^{\circ}$, 平均 $2.4^{\circ}$ 急であった。

2. 前茵誘導板 $\mathrm{P} 2$ 装着時 (表11)

前宷誘導板 $\mathrm{P} 2$ の実験的粜牙誘導は, $\mathrm{P} 2 \angle \mathrm{FH}-$ 1 1が， $\angle \mathrm{FH}-1 \overline{1}$ よりも $25^{\circ}$ 急になるように製作 したが, 実測では $17.0 \sim 41.5^{\circ}$, 平均 $24.2^{\circ}$ 急であった。

この時の顆頭最高点の動きが $\mathrm{FH}$ 平面となす角度 $\mathrm{P} 2$ $\angle \mathrm{FH}$ to $\mathrm{C}-\mathrm{C}_{1}$ は, 最小 $33.0^{\circ}$, 最大 $63.0^{\circ}$, 平均 $46.6 \pm 8.4^{\circ}$ であった. てれは $\angle \mathrm{FH}$ to $\mathrm{C}-\mathrm{C}_{1}$ よりも $1.5 \sim 8.0^{\circ}$, 平均 $4.3^{\circ}$ 急であった。

3. 前菌誘導板 P 3 装着時（表12）

前䨑誘導板 P 3 の実験的雬牙誘導は, P $3 \angle \mathrm{FH}-$ $1 \overline{1}$ が $\angle \mathrm{FH}-1 \overline{1}$ よりも $4.0 \sim 44.5^{\circ}$, 平均 $16.6^{\circ}$ 急になるような雪牙誘導となった。また咬頭炭合位から 切端咬合位までの下䋶中切霜の移動距離は $4 \mathrm{~mm}$ とし 
表11 P 2 装着時の計測值

\begin{tabular}{c|c|c|c|c}
\hline \hline 被験者 & $\begin{array}{r}\mathrm{P} 2 \angle \mathrm{FH} \\
-1\end{array}$ & 変化量 & $\begin{array}{r}\mathrm{P} 2 \angle \mathrm{FH} \text { to } \\
\mathrm{C}-\mathrm{C}_{1}\end{array}$ & 変化量 \\
\hline 1. & 60.0 & 23.0 & 43.0 & 5.0 \\
2. & 79.0 & 26.0 & 50.0 & 4.5 \\
3. & 58.0 & 21.0 & 37.5 & 3.5 \\
4. & 75.0 & 22.0 & 52.5 & 3.5 \\
5. & 68.0 & 31.0 & 53.5 & 2.0 \\
6. & 64.0 & 17.0 & 51.0 & 3.0 \\
7. & 69.0 & 22.5 & 51.5 & 3.0 \\
8. & 74.0 & 18.0 & 34.5 & 4.0 \\
9. & 56.0 & 41.5 & 45.0 & 6.0 \\
10. & 62.0 & 23.5 & 48.0 & 3.5 \\
11. & 85.0 & 21.5 & 53.0 & 7.5 \\
12. & 39.0 & 19.0 & 36.5 & 1.5 \\
13. & 65.0 & 30.0 & 47.0 & 5.5 \\
14. & 70.5 & 29.0 & 33.0 & 4.0 \\
15. & 72.0 & 18.0 & 63.0 & 8.0 \\
\hline$\overline{\mathrm{X}}$ & 66.4 & 24.2 & 46.6 & 4.3 \\
\hline $\mathrm{S.D}$ & 11.0 & 6.5 & 8.4 & 1.9 \\
\hline
\end{tabular}

単位: 度

表12 P 3 装着時の計測值

\begin{tabular}{|c|c|c|c|c|}
\hline 被験者 & $\begin{array}{r}\mathrm{P} 3 \angle \mathrm{FH} \\
-11\end{array}$ & 変化量 & $\begin{array}{r}\mathrm{P} 3 \angle \mathrm{FH} \text { to } \\
\mathrm{C}-\mathrm{C}_{1}\end{array}$ & 変化量 \\
\hline 1. & 54.0 & 17.0 & 46.0 & 8.0 \\
\hline 2 . & 58.0 & 5.0 & 46.0 & 0.5 \\
\hline 3. & 56.0 & 19.0 & 35.0 & 1.0 \\
\hline 4. & 58.0 & 5.0 & 51.0 & 2.0 \\
\hline 5. & 55.0 & 18.0 & 52.0 & 0.5 \\
\hline 6. & 61.0 & 14.0 & 52.0 & 4.0 \\
\hline 7. & 66.0 & 19.5 & 51.0 & 2.5 \\
\hline 8. & 65.0 & 9.0 & 34.0 & 3.5 \\
\hline 9. & 59.0 & 44.5 & 52.5 & 13.5 \\
\hline 10. & 55.0 & 16.5 & 48.5 & 4.0 \\
\hline 11. & 69.0 & 5.5 & 46.5 & 1.0 \\
\hline 12. & 52.0 & 32.0 & 55.0 & 15.0 \\
\hline 13. & 53.0 & 18.0 & 47.0 & 5.5 \\
\hline 14. & 63.0 & 21.5 & 34.5 & 5.5 \\
\hline 15. & 58.0 & 4.0 & 56.0 & 1.0 \\
\hline $\bar{X}$ & 58.8 & 16.6 & 47.1 & 4.5 \\
\hline S.D. & 5.1 & 11.0 & 7.2 & 4.5 \\
\hline
\end{tabular}

単位：度
た。

この時の顆頭最高点の動きが $\mathrm{FH}$ 平面となす牦度 $\mathrm{P} 3$ $\angle \mathrm{FH}$ to $\mathrm{C}-\mathrm{C}_{1}$ は, 最小 $34.0^{\circ}$, 最大 $56.0^{\circ}$, 平均 $47.1 \pm 7.2^{\circ}$ であった。てれは $\angle \mathrm{FH}$ to $\mathrm{C}-\mathrm{C}_{1}$ より も $0.5 \sim 15.0^{\circ}$, 平均 $4.5^{\circ}$ 急であった。

$\mathrm{F}$. 㖽関節形態, 前菌部被蓋状態, 顆頭の動きの関連 性について

正常咬合者 15 名之上䋶前突者 15 名0計30名について, 顎関節形態, 前崡部被蓋状熊, 顆頭の動きの関連性を検 討したところ，関節結節後壁傾斜度と切端咬合位までの 顆頭の動きとの間には，図10に示すように両者の間には 相関関係が認められなかった。

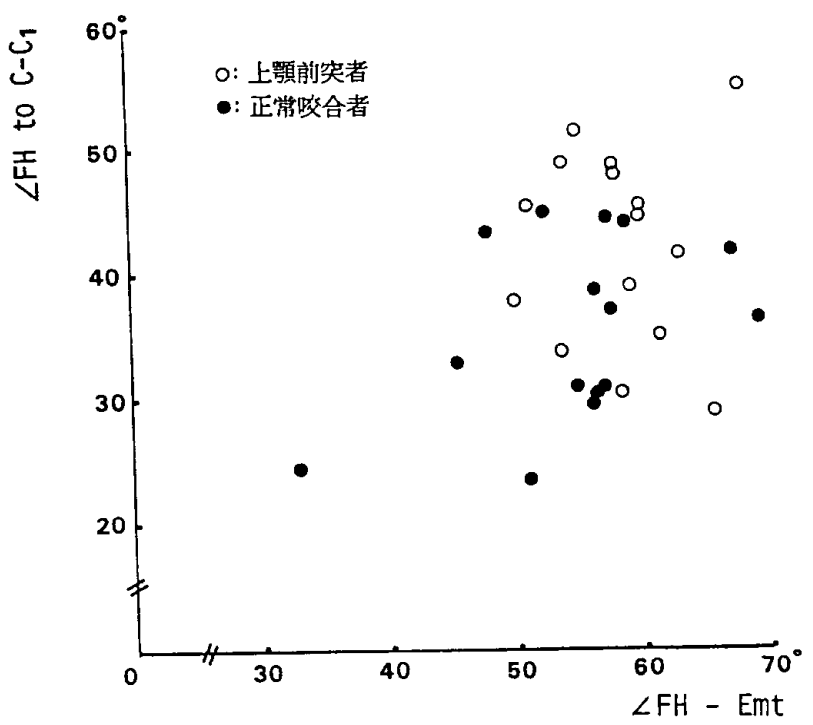

図10 関節結節後壁傾斜度と $\angle \mathrm{FH}$ to $\mathrm{C}-\mathrm{C}_{1}$ との関係

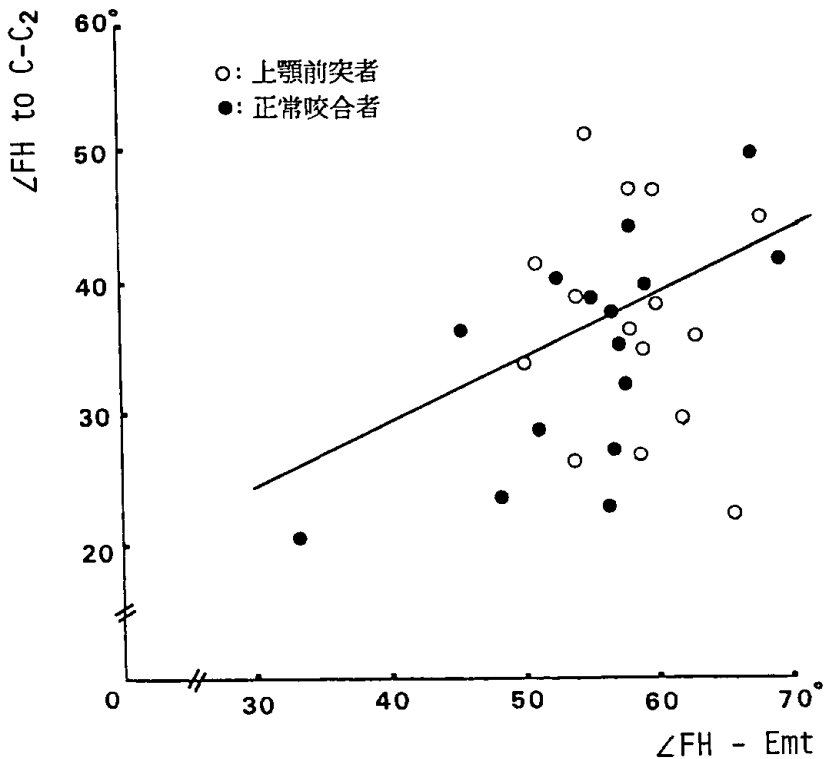

図11 関節結節後壁傾斜度と $\angle \mathrm{FH}$ to $\mathrm{C}-\mathrm{C}_{2}$ との関係 
また彗節結節後壁傾斜度と最前方接触位までの顆頭の 動きとの間には，図11亿示すように雨者の間には危険率 $5 \%(r=0.392)$ で正の相関関係が認められた。

次に上頻中切歯舌面傾斜と切端咬合位までの顆頭の動

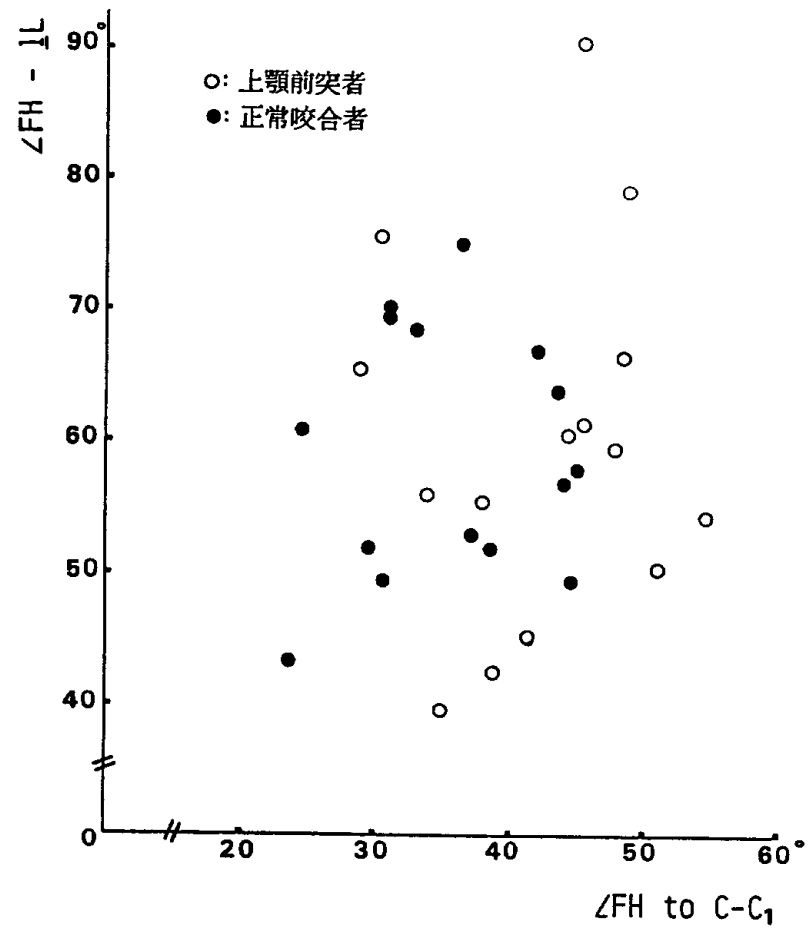

図12 $\angle \mathrm{FH}$ to $\mathrm{C}-\mathrm{C}_{1}$ と $\angle \mathrm{FH}-1 \mathrm{~L}$ との関係

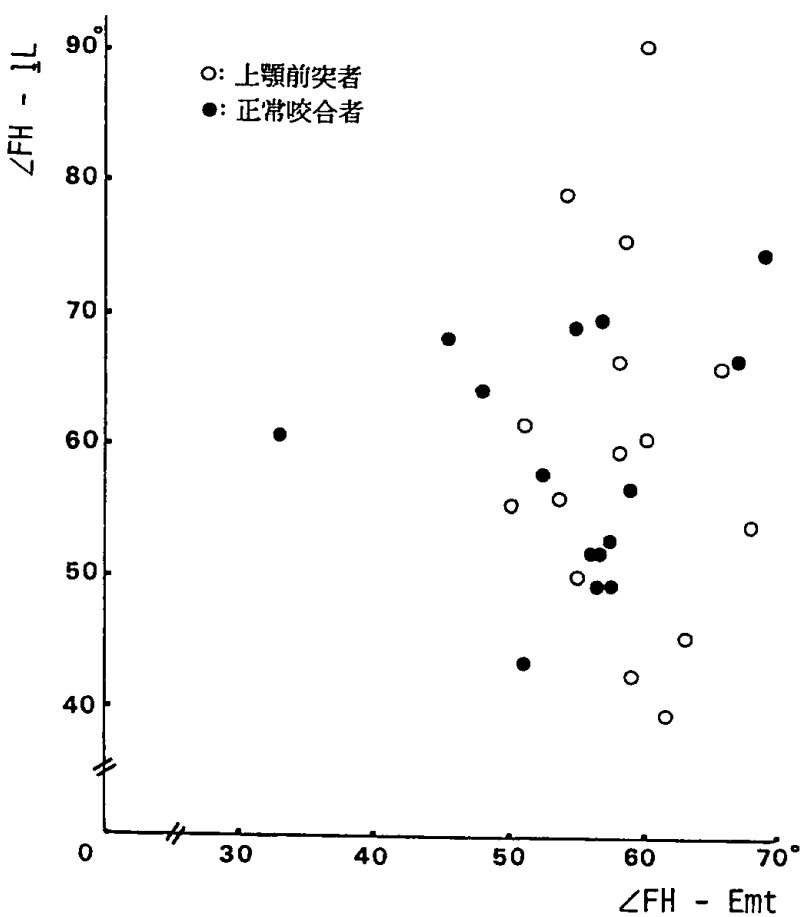

図13 関節結節後壁傾斜度と $\angle \mathrm{FH}-1 \mathrm{~L}$ との関係
きとの間には，図12に示すように両者の間には相関関係 が認められなかった。

さらに上顎中切曾舌面傾斜と関節結節後壁傾斜度との 間には，図13に示すように両者の間には相関関係が認め られなかった。

\section{考察}

A. 研究方法

1. 被験者

㖽関節形態および顆頭の動態の比較検討を行うにあた っては，性差あるいは成長変化による影響を除く必要が あるため, 被験者として $22 \sim 27$ 才，平均 24 才の成人男子 を用いた。

正常咬合者と上顎前突者の判定基準として, Angle の分類および overjet の量を用いたが，両者のセファロ 分析でも， $\angle \mathrm{SNB}, \angle \mathrm{ANB}, \angle \mathrm{NAP}, \angle \mathrm{AB}-\mathrm{NP}$, $\angle \overline{1}-\mathrm{Occ}, \underline{1}-\mathrm{NP}, \underline{1}-\mathrm{AP}$, overbite の各項目にお いて，両者間に有意の差が喼められた。すなわち本研究 での上顎前突者は, skeletal pattern では上頻の前方突 出よりも下顎の後退が著明で, denture patternでは上 顎前歯の唇側転位があり，かつ過蓋咬合を伴っていた。 てれは日本人の上顎前笑についての報告 ${ }^{14,15)}$ と一致し ている。

2. 撮影方法

今日までに頧関節のX線撮影方法は数多く報告されて いる ${ }^{16-19)}$ 。しかし, 通常の単純撮影法では顆頭の部分 に側頭骨の錐体部が重複したり，左右の頸関節像が重な りあったりするので，買関節形態や顆頭の動態を解析す るのは困難である，そこで本研究では，靧関節部に焦点 をあわせることにより，他の部との重複をさけうるとい う特徽をもつ断層撮影法を用いた。

断首撮影法においては，断層深度の決定が顎関節形態 を正確にとらえる重要なポイントとなる. Ricketts（19 50） ${ }^{20}$ は10個の乾燥頭蓋と 10 人の患者の研究で, 顆頭中 心点一皮膚間距離が $2.5 \mathrm{~cm}$ であったという事から， 2.5 $\mathrm{cm}$ と頭部固定台の厚み $1.0 \mathrm{~cm}$ を加えた $3.5 \mathrm{~cm}$ を断 首深度として断層撮影を行っている．また H jortsjö ら (1954) ${ }^{21}$ は, 以前に行った研究で顆頭中心点一頭蓋最 外側点の距離が $2.25 〜 3.25 \mathrm{~cm}$ であったということか ら，その中で最も明瞭汇顎関節が写し出される所をみつ け，その高さを断層深度とした．河野（1968）22'は，後前 撮影で顆頭一切歯点間距離を求め, 撮影台上より切歯点 までの距離から，ての長さを減じた距離を断層深度とし た. 中尾 ${ }^{13}$ は撮影台上から外眼角までの高さを計測し， 
これを断層深度とした。また，Beckwith ら (1980)23) はオトガイ一頭頂撮影により顆頭長軸の角度を求め， $\mathrm{X}$ 線が顆頭長軸と平行になるようにし，計算法により断層 樑度の決定を行うなど,各種の方法が発表されている.し かし，乙れらの方法でも顆頭が断風深度から外れていた り，抬大率修正がなされていないために顆頭中心点にお ける正確な断廉撮影が行われていないことがある。そこ で本研究ではさらに精度を高めるために，被験者の皮雷 上にスチールボールを貼付し，逆タウン $30^{\circ}$ の角度で咬 頭茨合位の後前撮影を行い，計算により正確に顆頭中心 点一皮膚間距離を求め，それに頭部規格固定台の厚みを 加えた距離を断層深度とした.その結果, 明膫な X線像 をうることができた。また断層撮影において，断磨深度 を変化させると拡大率が変化してくるが，本研究で用い た断層深度は 36〜 43mm で，その時の拡大率は 1.078 〜1.084 であり，ほとんど影響をうけないと思われる.

3. 前宩誘導板

雪牙誘導路を変化させるために人工的に菡牙誘導を与 える方法は，以前より行われている．Kurth $(1954)^{24) ， ~}$ Cohen (1956) ${ }^{25)}$, Clayton $(1971)^{26)}$ らは, 下䕱に central bearing screw をつけた clutch を装着し,上 顎には flat, concave, convex の3 種類の可撤性の誘 導路を与え，乙れにより菌牙誘導路の変更を行った。

Preiskel $\left(1970^{27)} ， 1972^{28}\right)$ は上顎犬蒾の口蓋面に 咬合高径を $1 \mathrm{~mm} ， 2 \mathrm{~mm}$ 增加させるような 2 種類の overlay を装着し，これを誘導路とした。鶴兄（1975） 29)は上顎口蓋部にアクリル板を，下顎の舌側にも咬合 平面と一致するようなアクりル板を装着し，咬合高径を 高めるととにより棵牙誘導路の変更を行った。しかし， これらの方法は咬合高径の変化, 顎運動の出発点の変 化, それに歯牙誘導路の変化と三つの要素が含まれてい るので，歯牙誘導路の変化による影響だけを検討するこ とが困難である。梁山（1979） ${ }^{30}$ は父牙誘導路だけを変 化させるために，上顎口蓋部に側方滑走運動時の切歯点 運動経路が約 $10^{\circ}$ ， および $20^{\circ}$ 急になるような 2 種類 の人工歯牙指導板を装着し，下顎の床につけた central bearing pin で誘導を行った。

本研究では純粋に前雪部被蓋状態変更の影響を知るた

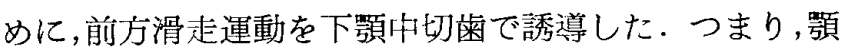
運動を下顎につけた central bearing pin で誘導する のではなく，下顎には何も装着せずに，上顎中切菊に装

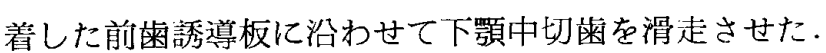
また, 咬合高径, 前方滑走運動の出発点を変化させない ために，咬頭嵌合位で前歯誘導板が下顎の歯牙に接触し
ないように，被験者の口腔内で調節を行った。前菌誘導 板のうち P 1，P 2 は，被験者の咬頭嵌合位から切端咬 合位までの下㖽前菌の移動距離を変更せずに, 舌面傾斜 角だけを変化させたために，角度の変化による影響だけ をとらえることができたＰ３は，治療後の上顎中切 雬の舌面の位置を想定して製作したために，下顎中切蒾 の移動距離と舌面傾斜度の二つの要素の変更を行ったこ ととなった。

それぞれの前雨誘導板を装着したセファロ撮影では， 前䨑誘導板の舌面に鉛線を貼付してあるので，セファ口 写真上で P 1，P 2，P 3 の傾斜角度を正確に計測する ことができた。

計測值は, P 1 が $4.5 \sim 31.5^{\circ}$, 平均 $14.6^{\circ}, \mathrm{P} 2$ が $17.0 \sim 41.5^{\circ}$, 平均 $24.2^{\circ}$, P 3 が $4.0 \sim 44.5^{\circ}$ 平均 16 . $6^{\circ}$ であった，各被験者のP $1 ， \mathrm{P} 2$ は鿓態模型上で予 定した増加度数で正確に製作したが，セファロ上で計測 してみると，多少ズレを生じていた。また P 3 は，セ ファロ上で overjet $2 \mathrm{~mm}$, overbite $3 \mathrm{~mm}$ になるよ うに製作したために，被験者間で変化量が暴った。

\section{B. 研究結果}

\section{1. 顎関節形態}

X線像により，顎関節形態，関節窩内での顆頭の位圆 を計測するのに，基準平面から各計測点までの距離，角 度を計測する方法 ${ }^{13}, 22,31$ と，顎関節空隙の占める割 合を測定し，それによって顆頭の位置を求める方法 32 ， 33)とがあるが，本研究では FH 平面を基準線として， 顎関節形漶, 顆頭位の計测を行った。

正常咬合者と上顎前突者について関節窩底の位䈯，関 節結節頂の位犆, 関節結節後壁傾斜度, 顆頭位の各計測 值間に差があるかどうか検定を行ったが，全ての項目で

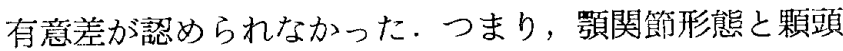
位には，正常咬合者と上顎前乫者では特徽的な差がな かったこととなる．すなわち㖽関節形態の差が，グルー プ閒よりむ允しろ個人間の方にあることを示すもので,

Ricketts $(1952)^{34)}$ も同様な意見を述べている.

また頍関節形態の中で，特に前方滑走運動と関連があ ると思われる関節結節後壁傾斜度は, 正常咬合者 54.7 $\pm 8.5^{\circ}$ ，上顎前突者 $58.3 \pm 5.1^{\circ}$ であった。同様に $\mathrm{FH}$ 平面に対して計澌を行った Ricketts ${ }^{31}$ は class I, class II とも $54.0^{\circ}$, 中尾 ${ }^{13}$ は正常咬合者で $60.05^{\circ}$ であったと報告している．また河野22)は咬合平面に対 し計測を行い，㖽関節に隌常の認められない者の平均で $55.7^{\circ}$ であったと報皆している.これらの值と著者の值 には大差はなかった。 


\section{2. 前方滑走運動時の顆頭の動き}

前方滑走運動は，咬頭嵌合位汃ら切端咬合倍を経て最 前方接触位まで，上下歯牙を接触させて行う運動であ る。河野ら 91は, 前方滑定運動に执いて咀嚼, 噮下等の 機能運動と密接な関連をもつのは，咬頭嵌合位から上顎 前歯舌面に誘導されて切端咬合位に至る理動と考え，マ ルチフラッシュ法により前方滑走運動の解析を行ってい る. 本研究ではX線像により前方滑走運動の解析を行っ たため，咬頭嵌合位の顆頭最高点と，切端咬合位あるい は最前方接触位の顆頭最高点とを結んで，乙れを運動路 とした。

咬頭嵌合位から切端唼合位に至る顆頭の動きは，正常 咬合者では角度が平均 $35.6^{\circ}$, 距離が平坛 $3.1 \mathrm{~mm}$, 上 顎前突者では角度が平均 $42.3^{\circ}$, 距離が平均 $7.1 \mathrm{~mm}$ で あった．河野22、は断層撮影により顆頭の移動距離を計 测し，切端咬合位では解分に平均 $4.2 \mathrm{~mm}$ ，下方へ 4.1 $\mathrm{mm}$ 移動したと報告している。荘島 $(1975)^{35}$ ) は側斜 方向 X線規格写真より，切粫咬合位までの顆頭の移動距

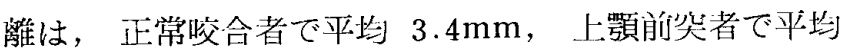
$6.1 \mathrm{~mm}$ と報告している。また, 顆頭運動の测走点とし て全運動軸を求め，乙れを测定点として写真法により計 测を行った河野 ${ }^{9)}$ は, 失状顆路角が芦均 $39.9^{\circ}$, 移動距 離が平均 $5.3 \mathrm{~mm}$ であったと報告し, 中野10'は矢状顆 路角がカンベル平面に対し平均 $37.5^{\circ}$ であったと朝告 している，斉藤 $(1979)^{36}$ 'は，Panadent 下顎連動記録 装置で咬頭嵌合位から切端咬合位をわずかにこえた位苦 までの計測を行い，矢状顆路角がK. axis一Or. planeに 対し平均 $55.2^{\circ}$ であると報告している。著者の值と青 島 $^{351}$ ，河野ら ${ }^{91}$ ，中野108の值とは大差はないが，染 藤 ${ }^{36)}$ の值とは正常咬合者で $20^{\circ}$ 近く差が生じている。 これは計測方法, 基準平面の堡いと, さらに運動量の違 いにより生じたものだと思われる。

正常咬合者之上額前突者との值を比較すると，角度， 距離上もに危険率 $5 \%$ で有意差を生じた。つまり，咬頭 嵌合位から切端咬合位に至る顆頭の動きが，正常咬合者 と上顎前突者とでは異っているといらてとである。乙れ は，正常咬合者と上顎前笑者とでは，前贯部被蓋状態が

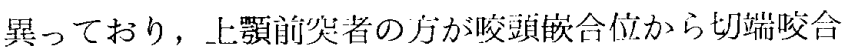
位までの下顎中比雪の移動距離が長いために，顆䫓の動

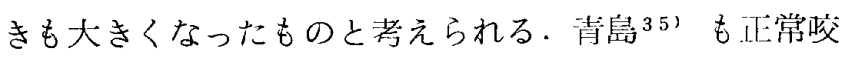
合者と上顎前乫者の顆頭の移動量を比較して，箸者と同 様な結果を得ている。また，横田（1976）37の開発した 咬合の検査機を用いて, 山地 $(1977)^{381}$ は正常咬合者と 反対咬合者の顎運動の解析を行い，両者間の顎運動の違
いは，前囦部被蓋状態の違いによって生じたと報告して いる、いずれにしても，前歯部被蓋状態が顎運動に影響 を手えているととは確かであると思われる。

次に，咬頭嵌合位汃ら最前方接触位に至る顆頭の動 きは，正常咬合者で角度が平毕 $34.9^{\circ}$, 距離が平均 8.2 $\mathrm{mm}$, 上䫇前突者で, 角度が平均 $37.1^{\circ}$, 距離が 10.4 $\mathrm{mm}$ であった。中尾13' は正常咬合者に $5 \mathrm{~mm}, 10 \mathrm{~mm}$ ， $15 \mathrm{~mm}$ の円柱を咬ませた時の顆頭点を連ねた線を結ん で，乙れと鼻耳道線とのなす角度を失状顆路傾斜角度と し, 平烓 $33.64^{\circ}$ と報告している。河野22 は顆頭の移 動距離が前方に平勾 $10.0 \mathrm{~mm}$ ，下年に斗均 $4.1 \mathrm{~mm}$ で あると報告している。青島 ${ }^{35}$ は，且嫦咬合者で平均 $9.1 \mathrm{~mm}$ ，上䫟前突者で平均 $11.7 \mathrm{~mm}$ の移動距離であっ たと報告している。これらの値と著者の值には大差はな かった。

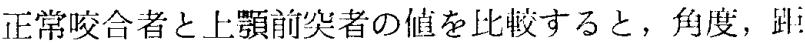
離とも差が認められなかった。したがって下筼の限界運 動は，前歯部被蓋状態による影響をらけないと考えられ る。

3. 前柬部被蓋状態

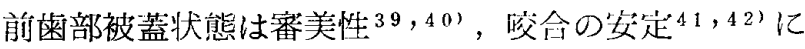
多大な影響を与えているが，前方滑起連動時の切粜誘博

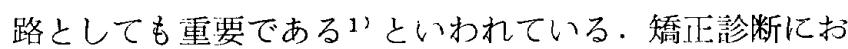
いては上顎中切雪粜軸傾斜角を計澌することが多いが， 前方滑走運動では，下顎中切迷が上顎中或㐘の舌面を消 起していくので，上頭中比粤の舌面傾斜角も計测する必 要がある.

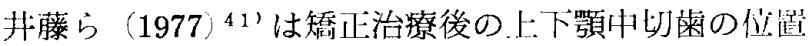
と傾斜について検討を行い，治療後の上顎前觉者之正常 咬合者の切踹の位置はほぼ一致しているが，歯軸傾斜が

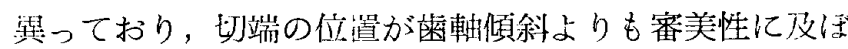

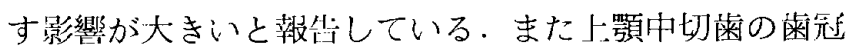
形態は，辺縁隆線や基成結節の発育状態により差があ る、これらからも, 矯正治療における上顎中切歯の位置 の沠垐には，歯軸傾斜角だけでなく，舌面傾斜角ならび に料軸傾斜と舌面傾斜とのなす角度も考慮に入れる必要 がある、本研究の結果では FH 平面に対し, 㾧軸傾斜 は国:常咬合者で平均 $64.3^{\circ} ，$ 上顎㓩乫者で平均 $61.4^{\circ}$, 舌面傾斜は正常咬合者で平均 $59.3^{\circ}$ ，1顎㓣突者で平均 $60.1^{\circ}$ 之，正常咬合者と上顎㓩垫者の間に差は誌められ なかった、霜軲傾斜之舌面傾䣄とのなす角度は，正常咬 合者で平均 $5.0^{\circ}$ ，上顎前突者で平均 $1.2^{\circ}$ であった。 このうち辽縁隆線の発育の弱い㐘牙が而常䝮合者で 2 例 $(13 \%) ， 上$ 枵前突者で 5 例 $(33 \%)$ あったが，乙れら 


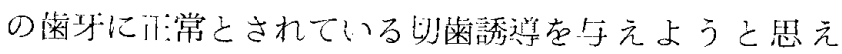

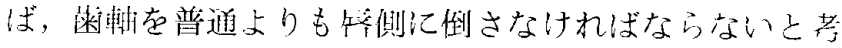
えられる。

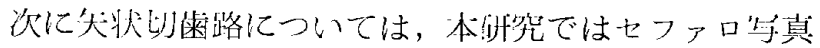
によりこれを求めたので，咬頭嵌合位時と切端咬合位時 の下顎中切料を結んだ線と FH 平面とのなす角度 $\mathrm{FH}-1 \overline{1}$ ) 在矢状切歯路角とした。著者の結装では成 常咬合者で平均 $43.9^{\circ}$ ，上顎㓩桇者で斗均 $42.2^{\circ}$ であ

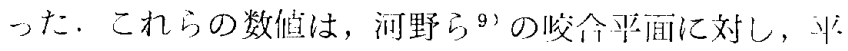

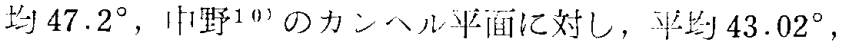

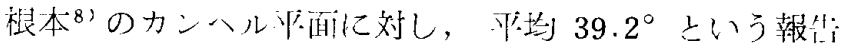
と大差はない.

Stallard と Stuart 1963“4，前方滑走連動時に

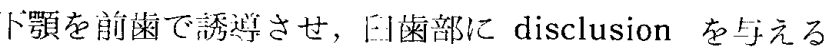
ことを理想としており，Mchorris (1979 43)は，スん ーズな disclusion を得るためには切䨓路が顆路よりも 5 。大きいことが理想であると献等している。

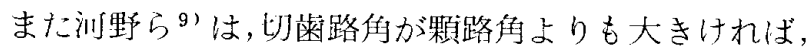

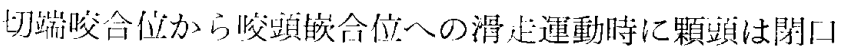
方向一回転するが，运に顆路角の方が大きければ，顆磌 は開的问へ回転することになるということと, Abe

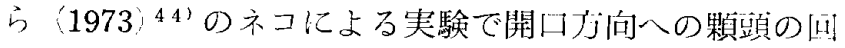
法連動が，咬朌 $\alpha$--連動線維の放留に抑制效果を与えた

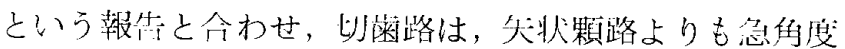

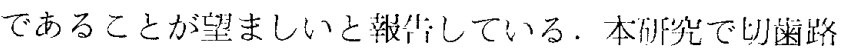
のうが顆路よりも鱼角度のものは，正常咬合者で15例月，

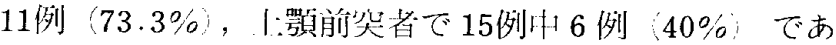

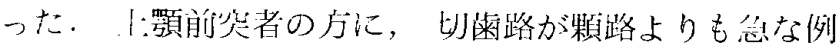
が少かったのは，overjet の大きい上顎解聟者では， FH一1 1 が沟るやかであったためである。

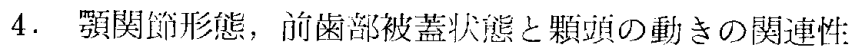
について

顎関临の形熊と機能の䦌の関係について Stallard と

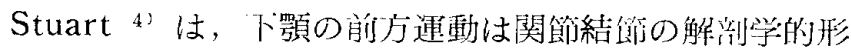
萔に影㗽を受けていると肬べている。しかし Jankelson

(1963) ${ }^{5}$ は，卜䫈の運動は顎関節形態の影響を受ける のではなく，関節窝内では関節包，関節靱装，朌肉の動

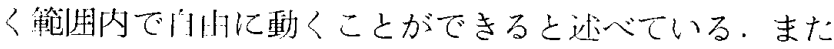

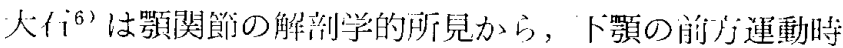

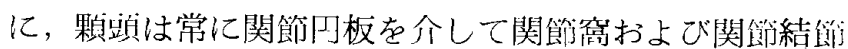

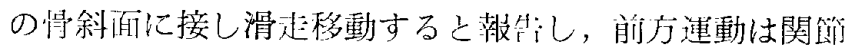

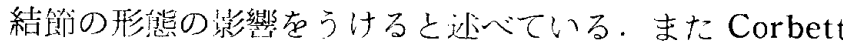
らマは，セファロと Panadent 下顎運動記録装置を用 いて，顆路と関節結節の形態との相関について検討を行

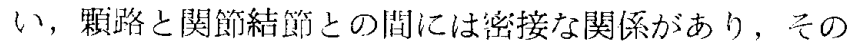
関係は 2 次方程式によって最もよく表わされると㣮占し

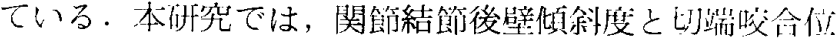

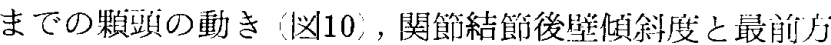
接触位までの顆頭の動き（欧11）について㥵関関係を 求めたところ, 後者に危険率 $5 \%$ で四の相関が認められ たっつまり，本砳究でも下顎を㓩方限界運動させた時の 顆暊の動きは，関節結節の形態と関連があると思わ机 る。しかし，以端咬命位までの顆䫓の動き之関節結節の 㓞態との間には関連がなかった。

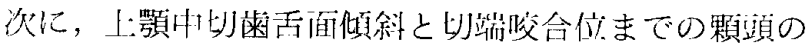

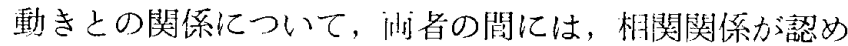
られなかった 脳12. Ingervall 1972 45 も condylar

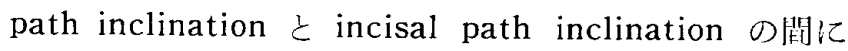
は，相関関係が認められなかったと報䈃している。 ま

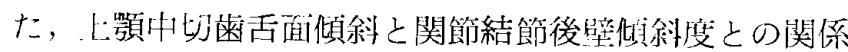
について，罒者の間には，相関関係は認められなかった

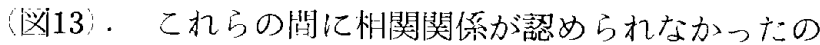

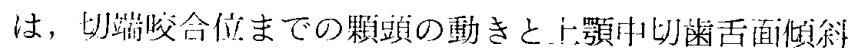
それに関節結節後壁傾斜ともに個人間の差が大きかった ためであると思われる。

5. 奏験的被蓋変更について

人[似に歯牙路在変えると，顆路も変化する $24,27,29$

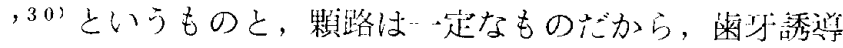
路を㝐えても変化しない25，26）という二つの相対する意

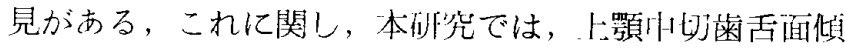
斜在平均 $14.6^{\circ}$ ( P 1 装着時) と $24.2^{\circ}$ ( $\mathrm{P}_{2}$ 装着時) 垤加させると，顆㖵の動きは，それぞれ平均 $2.4^{\circ}$ と $4.3^{\circ}$ 总になり，䏫者の意見之闰じであった。つまり， 与䪽中切歯舌面倾斜角を㙋加させ，切橉路を急にすれば するほど，顆韻の動きも念になるということである。.上

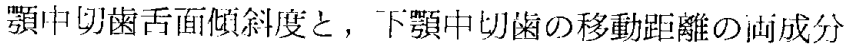
を変化させた P 3 は，P $1 ， \mathrm{P} 2$ 装着時とは杀件が異な

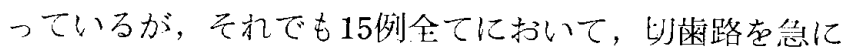

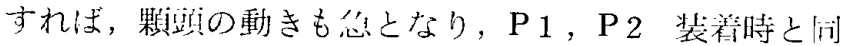

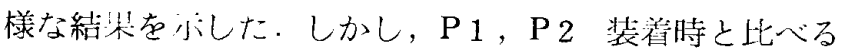
と，下顎打以米の移動距傩が $4 \mathrm{~mm}$ と少かったため

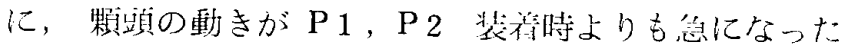
もの 15例胴 6 例 $40 \%$ ，綏やかになったもの15例㠴 1

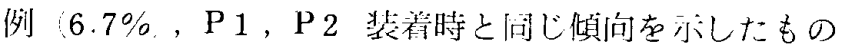
15例林 8 例 $53.3 \%$ であった。

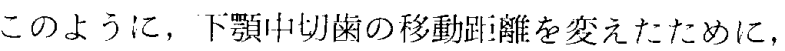
P 1，P 2 装看時と違った傾向を小したのは，下顠が解 方滑起連動を行う際に顆櫬の回轾と移動との割合が变化 
したためであると思われる：いずれにしても，㓱雨部

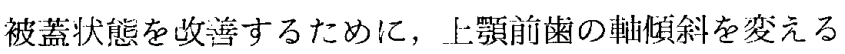
と，顆路も変わることになる。

小池 ${ }^{21}$ ，山内 ${ }^{2}$ は，顎関節形態のうち関節結節は，莊 合雨列期前期から中期にかけて後壁の傾斜が普加し，深 さも深くなると報告している。つまり，七顎中切霜の萌 出と共に, 関節結節は成長しているのである.

Humphreys $(1932)^{46}$ ) は, 関節結節の形成は $6 \sim 7$ 才まではまだ明胉ではなく,10才までにわずかに成言し， 10〜11才の間で最も忹盛な成長を行い，12\}で，大きさ は成人には達しないが形態はほ向同じになると報告して いる．乙の関節結節の成靑の著るしい混合藏列期に，矮 正治療では削菌部被蓋状態の改善を行うことが多い. 本 研究では, 前歯部被蓋状態の変更による顆路の変化を明 瞭に観察するために，成交の完了した成人男子を被験者 として用いたが, 得られた結果に成長を合わせて考察を 行ってみた。矯正治療により前柬部被蓋状態の改善を行 うと，顆頭の動きも変化することになる. Moss のいう 管格の成長は，機能を间じくする墖軟組織によって 決定されるという Functional matrix theory ${ }^{47}{ }^{481}$ に 従えば, 機能時の顆頭の動きの変化が, 関節結節の形成 に影響を与えるのではないかと推祭される。つまり，関 節結節の成長の旺盛な混合雬列期に, 前雨部の被蓋改善 を行い，上顎前爾の適切な位置を決定する之，顎関節の 形態もそれに伴って変化してくるのではないかと考えら れる. それ故に，混合雨列期の早期に前雨部被蓋状態の 改善を行うことは，額関節の良い成圭を行わせるために も重要であると思われる，また成長発青の笔了した患者 では, 顎関節における管の改造, 一下顎運動路の変化に対 する伤機能の順応など考慮すべきであると思われる．

\section{結}

\section{論}

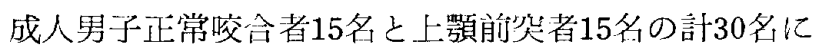
ついて, 頇関節規格断層撮影法を用いて, 䫚関節形態, 前方滑走運動の記録を行った。さらに，上:䋶削栄者につ いて，実験的に被蓋状態を変更したさいの前方滑走運動 の記録を行い，顎関節形態扔よび前歯部被蓋状態が前方
滑走運動に及ぼす影響について検討を行った結贸，次の 結論在得た。

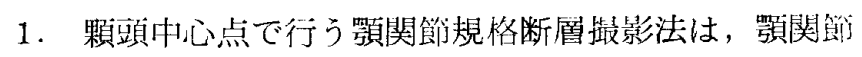
形態および顆頭の動きをみるのに大変有効な方法である ことが分った。

2. 正常咬合者と上頭前岱者の顎関節形態に相違は認め られなかった。

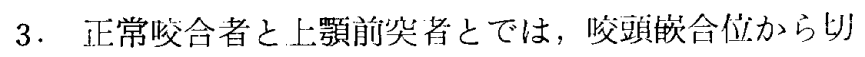

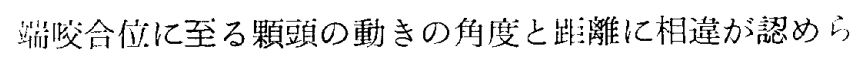
れ，上頭前突者の方がその仵度が大きく, 距離が烄かっ た.

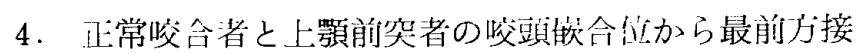
触位に至る顆頭の動きと, 関節結節後壁傾斜度との間に 正:の相関関係が認められた。

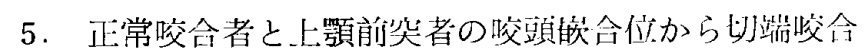
位に至る顆頭の動きと, 関節結節後壁傾斜度および上顎 中切雪舌面傾斜角之の間, また, 上顎中切菌舌面傾斜牦 と関節結節後壁傾斜度との間には, 㥵関関倸が認められ なかった。

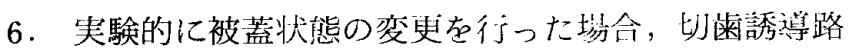
が急汇なれば，顆頭の動きも急になる傾向にあった。

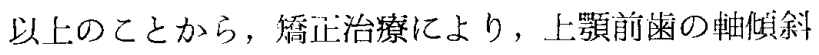
を変更すると㖽運動路も変わると考元られるので，穴の 点江㫐注意を払う必要がある。

稍を終わるにあたり，終始御愁篤なる御指導と御校閲

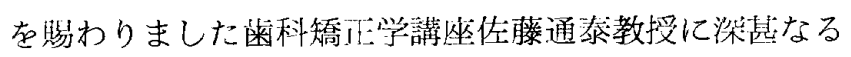
感謝り意を表します。

また種々の御助言と御校阅を唄わりました生理学講坐

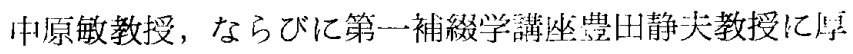
く御礼申しあげるとともに，放射楾掫影に種々の御助言 を賜わりました放射線学講坐大庭健教授ならびに中央 研究公小川泰夫博上に毞く御礼肘あげます。.

さらに，終始変わら双御教示をいただいた木原尤怗 た，白川安愿博上，分山英次博士に心から感謝の意を捧 げるとともに，本研究に御協力いただいた矯正学教公の 方々抢上び, 被験者の方々に心から感謝いたします。

\section{引用文献}

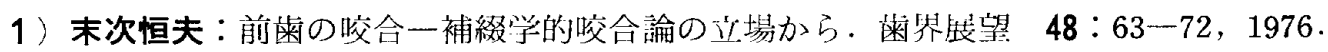

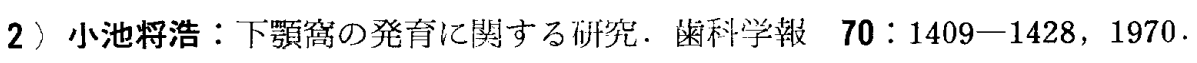

3）山内和夫：側頭鲑顎関節面の形態的成長とその意義. 広島大㐘誌 5:91-96，1973.

4 Stallard, H. and Stuart, C.E. : Concepts of occlusion. What kind of occlusion should recusped 
teeth be given? Dent. Clin. North Am. 591-606, 1963.

5 Jankelson, B. : Dental occlusion and the temporomandibular joint. Dent. Clin. North Am. $51-62,1963$.

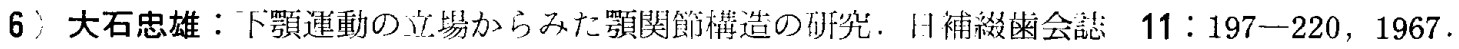

7 ) Corbett, N.E., DeVincenzo, J.P., Huffer, R. A. and Shryock, E. F.: The relation of the condylar path to the articular eminence in mandibular protrusion. Angle Orthod. 41:286-$292,1971$.

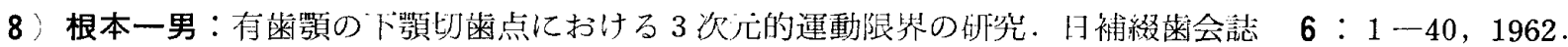

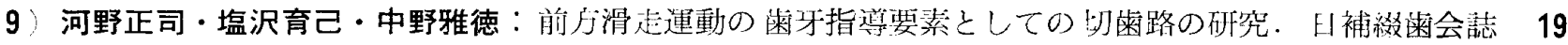
: 426-433, 1975 .

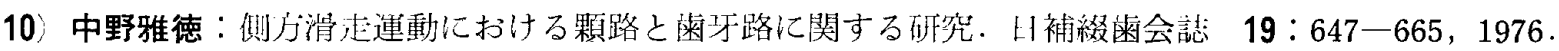

11) Huffer, R.A., DeVincenzo, J.P., Corbett, N. E. and Shryock, E. F. : Relationship between the lingual of the maxillary central incisor and the articular eminence in ideal occlusion. Angle Orthod. 42:44-49, 1972.

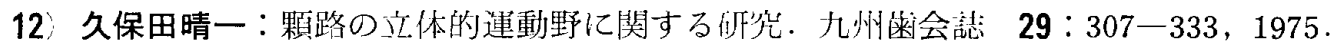

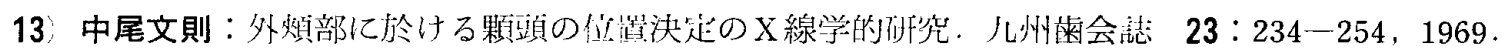

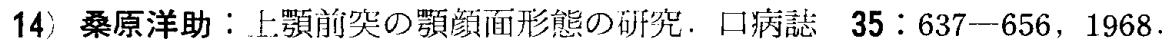

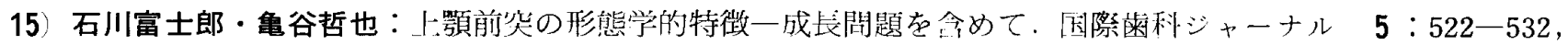
1977 .

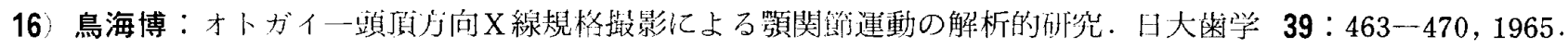

17) Weinberg, L.A.: An evaluation of duplicability of temporomandibular joint radiographs. $J$. Prosthet. Dent. $24: 512-541,1970$.

18 Weinberg, L.A. : What we really see in a TMJ radiograph. J. Prosthet. Dent. 30:898-913, 1973 .

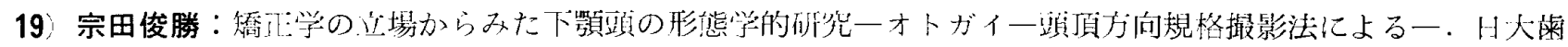

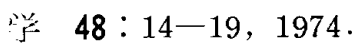

20 Ricketts, R.M. : Variations of the temporomandibular joint as revealed by cephalometric laminagraphy. Am. J. Orthod. $36: 877-898,1950$.

21) Hjortsjö, C.H., Persson, P.I., Sonesson, A. and Sonesson, B. : A tomographic study of the rotation movements in the temporomandibular joint during lowering and forward movement of the mandibule. Odont. Rev. $5: 81-110,1954$.

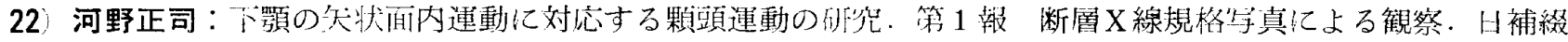
米会誌 $12: 337-349,1968$.

23) Beckwith, P.J., Monfort, D. R. and Williams, B. H. : Accurate depth of cut in temporomandibulr joint laminagraphs. Angle Orthod. 50:16-22, 1980.

24. Kurth, L.E. : Balanced occlusion. J. Prosthet. Dent. $4: 150-167,1954$.

25 Cohen, R. : The relationship of anterior guidance to condylar guidance in mandibular movement. J. Prosthet. Dent. $6: 758-767,1956$.

26 Clayton, J.A., Kotowics, W.E. and Myens, G. E. : Graphic recordings of mandibular movements. Research criteria. J. Prosthet. Dent. 25:287-298, 1971.

27 Preiskel, H.W. : Bennett's movement. A study of human lateral mandibular movement. Br. Dent. J. $129: 372-377,1970$.

28 Preiskel, H.W.: Ultrasonic measurements of movements of the working condyle. J. Prosthet. Dent. $27: 607-615,1972$. 


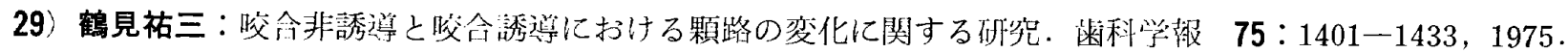

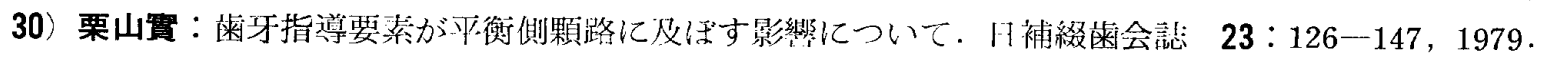

31) Ricketts, R.M. : Facial and denture changes during orthodontic treatment as analyzed from the temporomandibular joint. Am. J. Orthod. $41: 163-179,1955$.

32) Blaschke, D.D. and Blaschke, T.J. : A method for quantitatively determining temporomandibular joint bony relationships. J. Dent. Res. 60:35-43, 1981.

33) Blaschke, D.D. and Blaschke, T.J. : Normal TMJ bony relationships in centric occlusion. $J$. Dent. Res. 60:98-104, 1981 .

34) Ricketts, R.M. : Various conditions of the temporomandibular joint as revealed by cephalometric laminagraphy. Angle Orthod. 22:98-115, 1952.

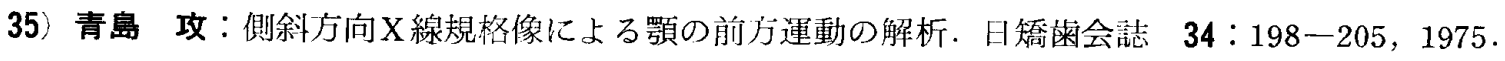

36）省藤文明：下顎頭の運動路に関する詶究。霜科学報 $79: 41-81 ， 1979$.

37）横田成三：完全な咬合器にもなる咬合検査機器“Occluder”。菊界展望 47：377一382，1976.

38）山地正樹：滑走運動における顆路の仿体的研究一正常咬合者および反対咬合者について一。州䨑会誌 30 : $989-1015,1977$.

39）瀬端正之・莱地 誠・野上宏一・原崎守弘・市村堅二：調和のとれた日本人側貎構成基準に関する研究.

1. Point A. B.と FH-U 1，FH-L 1 の相互関係について. 日镉歯会誌 28：61一67, 1969.

40）瀬端正之・菊地 誠・野上宏一・原畸守弘・市村棸二：調和のとれた日本人側貌構成基準に関する破究. 2. Point A. B. と FH-U 1，FH-L 1 の相互関係について. 日短蒾会誌 $28 ： 239-253,1969$.

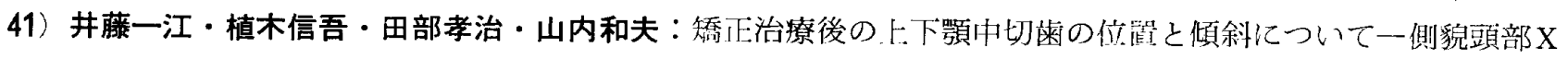

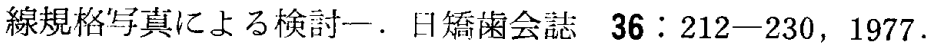

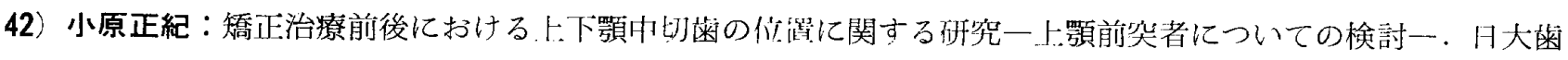
学 $54: 777-790,1980$.

43) Mchorris, W.H. : Occlusion with particular emphasis on the functional and parafunctional role of anterior teeth. Part 2. J. Clin. Orthod. 13:684-701, 1979.

44) Abe, K., Takata, M. and Kawamura, Y. : A study on inhibition of masseteric $\alpha-$ motor fibre discharges by mechanical stimulation of the temporomandibular joint in the cat. Archs Oral Biol. $18: 301-304,1973$.

45) Ingervall, B. : Range of sagittal movement of the mandibular condyles and inclination of the condyle path in children and adults. Acta. Odontol. Scand. 30:67-87, 1972.

46) Humphreys, H. : Age changes in the temporomandibular joint and their importance in orthodontics. Int. J. Orthod. $18: 809-815,1932$.

47) Moss, M.L. : Functional analysis of human mandibular growth. J. Prosthet. Dent. 10:11491159,1960 .

48) Moss, M.L.: The primary role of functional matrices in facial growth. Am. J. Orthod. 55: $566-577,1969$. 